2182Received 00th January 20xx Accepted 00th January 20xx

DOI: $10.1039 / x 0 x \times 00000 x$

\section{Higher fluorescence in platinum(IV) orthometallated complexes of perylene imine compared with their platinum(II) or palladium(II) analogues $^{\dagger}$}

\author{
J. Emilio Expósito, ${ }^{a}$ Marta Álvarez-Paíno, ${ }^{a}$ Gabriel Aullón, ${ }^{b}$ Jesús A. Miguel, ${ }^{* a}$ and Pablo Espinet*a \\ The reaction of 3-perylenylmethylen-4'-ethylaniline (1) with $\left[\mathrm{Pt}_{2} \mathrm{Me}_{4}\left(\mu-\mathrm{SMe}_{2}\right)_{2}\right]$ (and subsequent addition of $\left.\mathrm{PPh}_{3}\right)$ or with \\ $\left[\mathrm{Pt}_{2}\left(\eta^{3}-\mathrm{C}_{4} \mathrm{H}_{7}\right)_{2}(\mu-\mathrm{Cl})_{2}\right]$ produced cyclometallated $\mathrm{Pt}$ " complexes [Pt $\left.\left(\mathrm{C}^{\wedge} \mathrm{N}\right) \mathrm{Me}\left(\mathrm{PPh}_{3}\right)\right](2)$ and, respectively, $\left[\mathrm{Pt}_{2}\left(\mathrm{C}^{\wedge} \mathrm{N}\right)_{2}(\mu-\mathrm{Cl})_{2}\right]$ \\ (3) $\left(\mathrm{HC}^{\wedge} \mathrm{N}=3-\mathrm{C}_{20} \mathrm{H}_{11} \mathrm{CH}=\mathrm{NC}_{6} \mathrm{H}_{4}-p-\mathrm{C}_{2} \mathrm{H}_{5}\right)$, with Pt bound to the ortho site of the perylenyl fragment. From 3 the mononuclear \\ complexes $\left[\mathrm{Pt}\left(\mathrm{C}^{\wedge} \mathrm{N}\right) \mathrm{L}_{2}\right]\left(\mathrm{L}_{2}=\operatorname{acac}(4) ; \mathrm{S}_{2} \mathrm{COMe}(5) ; \mathrm{S}_{2} \mathrm{CNEt}_{2}(6)\right.$ are easily formed. Oxidative addition of methyl iodide to the \\ square-planar $\mathrm{Pt}$ " complexes $\mathbf{2}, \mathbf{4}$, and $\mathbf{6}$ gave the corresponding cyclometallated $\mathrm{Pt}^{\mathrm{IV}}$ compounds $\left[\mathrm{Pt}\left(\mathrm{C}^{\wedge} \mathrm{N}\right) \mathrm{L}_{2} \mathrm{Mel}\right] \mathbf{7}, \mathbf{8}$ and $\mathbf{9}$. \\ The X-ray structures of $\mathbf{4 , 6}$, and $\mathbf{7}$ show that the perylenyl fragment remains essentially flat in $\mathbf{4}$ and $\mathbf{6}$ and slightly twisted \\ in 7. Comparison of the optical properties of these Pt" complexes with those reported for similar Pd" derivatives reveals \\ that the change of metal exerts a notable influence on the Vis-UV spectra. In solution at room temperature, all the Pt \\ complexes, exhibit fluorescence associated to the perylene fragment with low emission quantum yields for the Pt" \\ complexes $(<1 \%)$ and remarkably higher emision values for the $\mathrm{Pt}^{\mathrm{IV}}$ complexes: up to $29 \%$, with emission lifetimes $1-5 \mathrm{~ns}$. \\ Time-dependent density functional theory (TD-DFT) calculations were performed to analyse the absorption spectra of the \\ perylene imine, and representative complexes $\left[\mathrm{M}\left(\mathrm{C}^{\wedge} \mathrm{N}\right)(\mathrm{acac})\right](\mathrm{M}=\mathrm{Pd}, \mathrm{Pt})$ and $\left[\mathrm{Pt}\left(\mathrm{C}^{\wedge} \mathrm{N}\right)(\mathrm{acac}) \mathrm{Mel}\right]$, which support a \\ perylene-dominated intraligand $\pi-\pi^{*}$ emissive state, based on the HOMO and LUMO orbitals of the perylene \\ chromophore, and a ligand-to-ligand charge-transfer (more intense for the Pt" complex) that explains the observed \\ influence of the metal on the absorption properties.
}

\section{Introduction}

Perylene derivatives are chromophores with exceptional chemical and photochemical stability, strong absorption of visible light and high fluorescence quantum yields. Due to these optical properties they have been used or explored in optical and electronic applications. ${ }^{1}$ Their solubility, electronic and optical properties can be significantly modified by varying the substituents in the aromatic core. The incorporation of metal centres and their ancillary ligands opens an easy way to modify the optoelectronic properties of the material and is an efficient way to create new structural and functional motifs, significantly widening the diversity of photofunctional systems available. ${ }^{2}$

The presence of late transition metals exhibiting large spin-orbit coupling $(\mathrm{SOC})$ in organic chromophores allows for facile tuning of the excited states, mainly because the SOC promotes very high rate $\left(10^{-12} \mathrm{~s}^{-1}\right)$ intersystem crossing (ISC) from singlet into triplet excited states (quenching the fluorescence), and can facilitate the triplet $\rightarrow$ singlet radiative transition (phosphorescence), modifying the photochemistry and photophysics and, as a result, their potential

\footnotetext{
a. IU CINQUIMA/Química Inorgánica, Facultad de Ciencias, Universidad de Valladolid, 47071 Valladolid (Spain).

${ }^{b .}$ Departament de Química Inorgànica, Universitat de Barcelona, Martí i Franquès 1-11, E-08028 Barcelona, (Spain)..

+ Electronic Supplementary Information (ESI) available: Absorption spectra of $\mathbf{4}$ in different solvents at room temperature; Emission and excitation spectra of $\mathbf{4}$ and $\mathbf{8}$ in MeTHF at $298 \mathrm{~K}$ and $77 \mathrm{~K}$; NMR spectra; Molecular orbitals and calculated absorption spectra parameters for perylene imine $\mathrm{HC}^{\wedge} \mathrm{N}$ and complexes $\left[\mathrm{M}\left(\mathrm{C}^{\wedge} \mathrm{N}\right)(\mathrm{acac})\right](\mathrm{M}=\mathrm{Pd}, \mathrm{Pt}),\left[\mathrm{Pt}\left(\mathrm{C}^{\wedge} \mathrm{N}\right)(\mathrm{acac}) \mathrm{Mel}\right]$ in gas phase and chloroform solution. CCDC reference numbers 1409783 for 4, 1409784 for 6, and 1409785 for

7. For ESI and crystallographic data in CIF or other electronic format see DOI: $10.1039 /$ b000000x
}

applications. For this reason the fluorescence of transition metal compounds is very difficult to observe but not impossible, ${ }^{3}$ and using perylene as chromophore, we have reported Pt" complexes of perylene and perylene monoimide with Pt $\sigma$-bonded directly to the perylene core, where the coordination of Pt has only a moderate quenching effect and the complexes show intense fluorescent emissions. We have reported also high fluorescence properties perylene derivatives with gold, palladium or platinum complex fragments attached to perylene through a tetrafluorophenyl linker, associated to the fact that the $\pi$-systems of the perylene and tetrafluorophenyl fragments are uncoupled; ${ }^{4}$ or with an isocyanide group acts as a connector between a $\mathrm{Au}, \mathrm{Pd}, \mathrm{Cr}, \mathrm{Mo}, \mathrm{W}$ complex fragments and the perylene chromophore, for which theoretical calculations indicate a very weak interactions of the metal with the $\pi$-system of the perylene. ${ }^{5}$

A different possibility to build metal derivatives bearing perylene fragment has been the functionalization of perylene with an imine group. Using Pd derivatives, our group reported the first examples of five or six-membered metallacyclic complexes derived from the 3-perilenylmethylen-4'-ethylaniline ligand, with two different bonding modes to $\mathrm{Pd}^{\prime \prime}$ derived from the two possible metallation sites of the 3-substituded perylene. ${ }^{6}$ In contrast to our previously mentioned results, the perylene imine and their cyclopalladated complexes had very modest quantum yields (in the range $0.04-0.13$ ).

Frequently the optical properties of metal-containing molecules are noticeably modified upon changing the metal, so we have considered of interest to replace Pd for Pt in the later complexes. In fact cyclometallated imine $\mathrm{Pt}$ " complexes have been thoroughly studied for their reactivity reactivity ${ }^{7}$ and applications. ${ }^{8}$ 
Particularly, those derived from 2-phenyl pyridine or related molecules, have been widely investigated due to their luminescent properties. ${ }^{9}$ Usually, the singlet excited state is completely quenched by the ISC process and room-temperature phosphorescence can be observed due to radiative decay from triplet metal-to-ligand charge-transfer (MLCT), ligand-centered (LC or $\left.\pi-\pi^{*}\right)$, mixed LC/MLCT or metal-metal-to-ligand charge transfer (MMLCT) states. ${ }^{10} \mathrm{~A}$ ligand field-induced destabilisation of metalcentered emissive states and rigidity of the ligand generally favour luminescence over non-radiative decay pathways. Other more conventional cyclometallated compounds have been extensively studied for luminescence, a few of them based on imines. ${ }^{11}$ In the present study the cycloplatinated compounds derived from perylene allow us to compare their optical properties as a function of the higher aromaticity of the ligand and other structural changes.

The luminescent properties of the material should be influenced by the oxidation state of the metal complex. $\mathrm{Pd}^{\mathrm{IV}}$ complexes are often highly oxidant and decompose easily, but $\mathrm{Pt}^{\mathrm{IV}}$ complexes are accessible and fairly stable. Therefore we have obtained the corresponding hexacoordinated $\mathrm{Pt}^{\mathrm{IV}}$ derivatives by oxidation of the square-planar cycloplatinated Pt" complexes with $\mathrm{Mel}$ and compared the luminescent properties of $\mathrm{Pt}^{\mathrm{II}}$ and $\mathrm{Pt}^{\mathrm{IV}}$ derivatives. Studies on their excited-state properties of $\mathrm{Pt}^{\mathrm{IV}}$ complex reported are scarce, ${ }^{12,13}$ in contrast with other $\mathrm{d}^{6}$ ions ( $\mathrm{Re}^{\prime}, \mathrm{Ru}^{\prime \prime}, \mathrm{Os}^{\prime \prime}$ and $\left|{ }^{\prime \prime \prime}\right|$ ) that have been extensively studied. ${ }^{14}$ Thus, the results reported here fill a gap in the knowledge of these systems.

\section{Results and discussion}

\section{Syntheses and Structures}

The syntheses of the orthoplatinated complexes are given in Scheme 1. Metalation of 3-perylenylmethylen-4'-ethylaniline 1 by reaction with $\left[\mathrm{Pt}_{2} \mathrm{Me}_{4}(\mu \text {-SMe })_{2}\right]$, and subsequent addition of $\mathrm{PPh}_{3}$ (the $\mathrm{SMe}_{2}$ intermediate is not amenable to crystallization due to its low stability) in a 1:1 molar ratio, led to complex 2 as a red solid. The ${ }^{1} \mathrm{H}$ NMR spectrum of $\mathbf{2}$ supports its isomeric purity, and NOE effect with the perylene proton adjacent to the metallation site of the methyl group supports a ligand arrangement with the phosphorous atom cis to the iminic nitrogen (Scheme 1), in coincidence with the results obtained for analogous aryl cyclometallated compounds. ${ }^{15,16,17}$ Cycloplatinated compounds are also accessible by reacting $\left[\mathrm{Pt}_{2}(\mu-\mathrm{Cl})_{2}\left(\eta^{3}-\mathrm{C}_{4} \mathrm{H}_{7}\right)_{2}\right]$ with $\mathbf{1}$ to give $\mathbf{3}^{18}$ which also showed the same isomeric selectivity towards fivemembered endo cyclometallated $\mathrm{Pt}(\mathrm{CN})$, as supported by ${ }^{1} \mathrm{H}$ NMR spectroscopy in DMSO-d ${ }^{6}$.

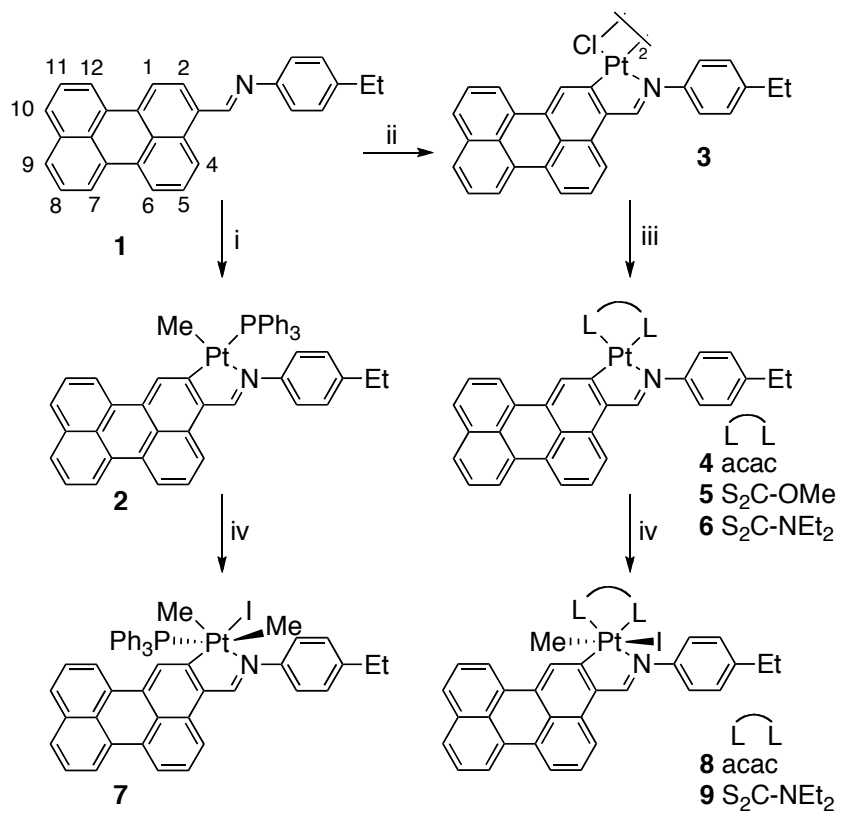

Scheme 1 i) $\left[\mathrm{Pt}_{2} \mathrm{Me}_{4}\left(\mu-\mathrm{SMe}_{2}\right)_{2}\right], \mathrm{PPh}_{3}$; ii) $\left[\mathrm{Pt}_{2}(\mu-\mathrm{Cl})_{2}\left(\eta^{3}-\mathrm{C}_{4} \mathrm{H}_{7}\right)_{2}\right]$; iii) [TI(acac)] (for 4), $\mathrm{KOH}+\mathrm{MeOH}, \mathrm{CS}_{2}$ (for 5), $\mathrm{NaS}_{2} \mathrm{CNEt}_{2}$ (for 6); iv) Mel.

Other compounds containing five-membered platinacycles, were synthesized from $\mathbf{3}$ as shown in Scheme 1. Thus, reaction of $\mathbf{3}$ with [ $\mathrm{TI}(\mathrm{acac})]$ in dichloromethane provided $\mathbf{4}$ as a purple red solid. Similarly, the reaction of $\mathbf{3}$ with a solution of $\mathrm{KOH}$ in methanol (1 M) and $\mathrm{CS}_{2}$ in dichloromethane afforded the xanthate complex 5 . The diethyldithiocarbamate complex $\mathbf{6}$ was prepared from $\mathbf{3}$ and excess of sodium diethyldithiocarbamate (1:3 molar ratio) in a mixture of dichloromethane/acetone $=1: 1$ at room temperature. Comparing the ${ }^{1} \mathrm{H}$ NMR parameters of these Pt complexes with their Pd analogues ${ }^{6 \mathrm{~b}}$ shows that the main difference is a slight deshielding observed for the imine proton and for $\mathrm{H} 1$ (0.15 - $0.25 \mathrm{ppm}$ ) in the Pt complexes. The structures of $\mathbf{4}$ and $\mathbf{6}$ were assessed by single crystal $\mathrm{X}$-ray diffraction (see below).

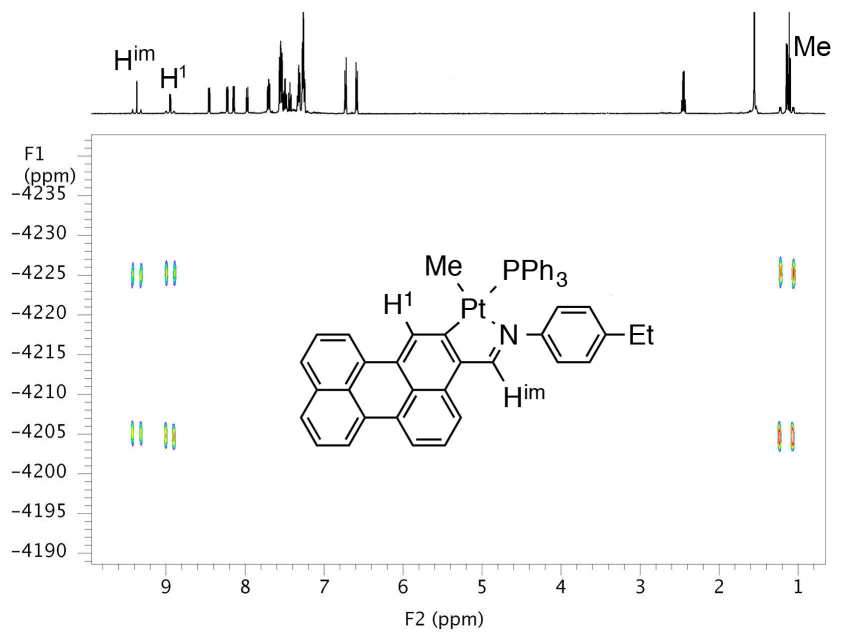

Fig. $1{ }^{1} \mathrm{H} /{ }^{195} \mathrm{Pt} 2 \mathrm{D}$ gHMBC spectrum of $2 .{ }^{1} \mathrm{H}$ NMR resonances in $\mathrm{F} 2$ and ${ }^{195} \mathrm{Pt}$ NMR resonances in $\mathrm{F} 1$. 
Table 1 Selected NMR parameters for compounds $\mathbf{2}-\mathbf{9}^{\mathrm{a}}$ in $\mathrm{CDCl}_{3}$

\begin{tabular}{ccccc}
\hline Comp. & $\delta^{195} \mathrm{Pt}$ & $\begin{array}{c}\delta \mathrm{H}^{\text {imine }} \\
\left({ }^{3} J_{\mathrm{Pt}-\mathrm{H}}\right)\end{array}$ & $\begin{array}{c}\delta \mathrm{H}^{1} \\
\left({ }^{3} J_{\mathrm{Pt}-\mathrm{H}}\right)\end{array}$ & $\begin{array}{c}\delta^{31} \mathrm{P} \\
\left({ }^{1} J_{\mathrm{Pt}-\mathrm{P}}\right)\end{array}$ \\
\hline $\mathbf{2}$ & -4215 & $9.37(53)$ & $8.94(51)$ & $29.8(2182)$ \\
$\mathbf{3}^{\mathrm{b}}$ & - & $9.25(112)$ & $9.44(42)$ & \\
$\mathbf{4}$ & -2874 & $8.94(133)$ & $8.62(35)$ & \\
$\mathbf{5}$ & -3939 & $9.12(120)$ & $8.17(79)$ & \\
$\mathbf{6}$ & -3712 & $9.19(111)$ & $8.19(60)$ & \\
$\mathbf{7}$ & -3345 & $8.82(44)$ & $7.86(48)$ & $-4.6(1015)$ \\
$\mathbf{8}$ & -2392 & $8.83(109)$ & $8.64(27)$ & \\
$\mathbf{9}$ & -3189 & $9.05(90)$ & $8.20(41)$ & \\
${ }^{\mathrm{a}} \delta$ in ppm and $J$ in Hz. ${ }^{b}$ in DMSO-d & &
\end{tabular}

The oxidation of 2-6 with methyl iodide in acetone or THF at room temperature gave the corresponding $\mathrm{Pt}^{\mathrm{IV}}$ compounds $\mathbf{7 - 9}$. The reaction with $\mathbf{5}$ failed to give the corresponding $\mathrm{Pt}^{\mathrm{IV}}$ complex. The structure of $\mathbf{7}$ was characterized crystallographically (see below). Comparing the ${ }^{1} \mathrm{H}$ NMR parameters of 7-9 with those of 2-6 a slight upfield shift of all the aromatic protons and a decrease in value of ${ }^{3} J_{\mathrm{Pt}-\mathrm{H}}$ (for the imine proton, from 53 to $44 \mathrm{~Hz}$ for 7; from 133 to 109 $\mathrm{Hz}$ for 8; from 111 to $90 \mathrm{~Hz}$ for 9 ) are observed, consistent with the higher oxidation state of Pt. In adition, the ${ }^{31} \mathrm{P}$ NMR spectrum of $\mathbf{7}$ is also a diagnostic of the Pt center oxidation state as the observed chemical shift at $\delta-4.6 \mathrm{ppm}$, is $35 \mathrm{ppm}$ upfield the corresponding Pt" precursor 2; the reduced ${ }^{1} \mathrm{~J}_{\mathrm{Pt}-\mathrm{P}}$ coupling constant $(1015 \mathrm{~Hz})$ is also consistent with formation of $\mathrm{Pt}^{\mathrm{IV}} \cdot{ }^{14,19,20,21}$ The ${ }^{195} \mathrm{Pt}$ NMR resonances were located indirectly by ${ }^{195} \mathrm{Pt} /{ }^{1} \mathrm{H} 2 \mathrm{D} \mathrm{HMBC}$ experiments (see Fig. 1), which shows the expected coupling constants as assigned in the experimental part.

\section{Crystal structures}

The single-crystal $\mathbf{X}$-ray crystal structures of $\mathbf{4 ,} \mathbf{6}$ and $\mathbf{7}$ are shown in Fig. 2, and selected bond lengths and angles are given in Table 1. They confirm in all cases the structures proposed in Scheme 1 . The Pt atom is always metallated at the ortho carbon $C(2)$, yielding a five-membered endo metallacycle.

For $\mathbf{4}$, and $\mathbf{6}$ the coordination around the Pt center is a distorted square-planar geometry. Most bond angles at $\mathrm{Pt}$ are close to the ideal value of $90^{\circ}$ (the maximum deviations are found for the angles $\mathrm{C}-\mathrm{Pt}-\mathrm{N}=80.77(10)^{\circ}$ for $\mathbf{4}$ or $79.58(18)$ for $\mathbf{6}$; and by $\mathrm{S}(1)-\mathrm{Pt}-\mathrm{S}(2)=$ $74.39(5)^{\circ}$ for 6 . These distortions are typical in reported cyclometallated $\mathrm{Pt}$ " complexes with five-membered metallacycles, and the S-Pt-S "bite" angle is very similar to those found in Pd for xantate or carbamate derivatives. ${ }^{6 \mathrm{~b}}$ The perylene fragment in $\mathbf{4}$ or $\mathbf{6}$ is essentially planar; the dihedral angle of the two "naphthalene" moieties forming the perylene fragment is $3.11^{\circ}$ for 4 and $3.40^{\circ}$ for 6. Both structures have almost planar five-membered metallacycles (mean deviations from the least-squares of $0.0065 \AA$ for $\mathbf{4}$ and $0.0061 \AA$ for 6$)$, ${ }^{6}$ approximately coplanar with the average plane of perylene fragment and with the coordination plane of platinum (the dihedral angles are, respectively, $3.44^{\circ}$ and $3.11^{\circ}$ for 4 , and $4.61^{\circ}$ and $4.05^{\circ}$ for 6$)$. The Pt-O bond lengths in the acac complex 4 (1.9982(19), 2.0881(19)) or the Pd-S bond lengths in the carbamate complex 6 (2.3969(14), 2.2802(14)) reflect the dissimilar trans influences of $\mathrm{N}$ - and $\mathrm{C}$-donors. ${ }^{22}$

In the crystal, $\mathbf{4}$ is a flat molecule except for the rotationally free phenyl group of the imine ligand, which is twisted an angle of $42.18^{\circ}$ respect to the coordination plane of platinum). The molecules of 4 pack in parallel planes with no $\pi-\pi$ stacking of the perylenyl rings, an inter ring distance of $3.19 \AA$, and a Pt...Pt interaction of $3.482 \AA$. Different from the acetylacetonate complex, in the diethyldithiocarbamate derivative 6 the molecules arrange in two systems of parallel planes forming between them a dihedral angle of $51.35^{\circ}$. There is no $\pi-\pi$ stacking of the perylenyl rings and the shortest Pt-Pt intermolecular distance is $7.465 \AA$.

Compound $\mathbf{7}$ crystallizes as an acetone solvate $\mathbf{7} \cdot\left(\mathrm{O}=\mathrm{CMe}_{2}\right)$ and exhibits a distorted octahedral coordination around the platinum atom with the usual fac $-\mathrm{PtC}_{3}$ arrangement and the bulky triphenylphosphine in the less hindered position, which is trans to a Me group. ${ }^{15}$ The coordination angles are close to the ideal value of $90^{\circ}$ (the maximum deviation is represented by the angle $\mathrm{C}(2)-\mathrm{Pt}(1)-$ $\mathrm{N}(1)$ of $\left.79.15(14)^{\circ}\right)$. The planar five-membered metallacycle is coplanar with the "naphthalene" moiety bonded to $\mathrm{Pt}(1)$ (dihedral angle of $1.91^{\circ}$ ). However, the perylene fragment is far from planar with a dihedral angle of $10.00^{\circ}$ between the two "naphthalene" halves forming the perylene. Obviously, this prevents $\pi-\pi$ stacking of the perylenyl rings.
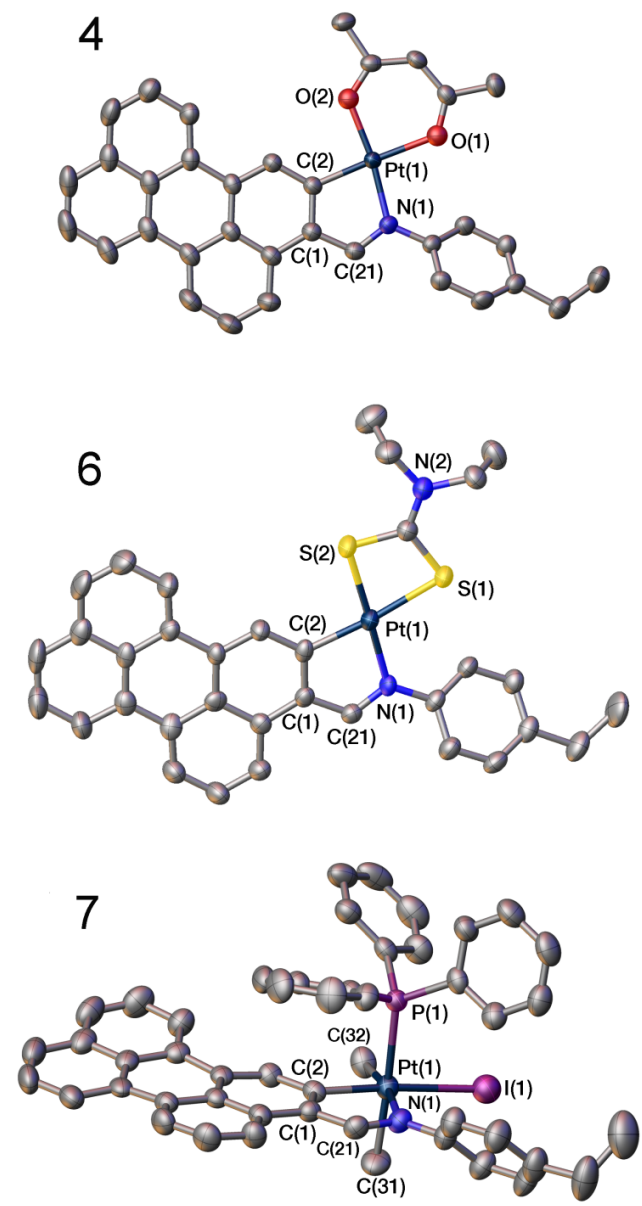

Fig. 2 ORTEPs of the crystal structures of complexes 4,6 and 7. (H atoms are omitted for clarity). 
Table 1. Selected Interatomic Distances $(\AA)$ and Angles $\left({ }^{\circ}\right)$ for the complexes 4, 6 and $\mathbf{7}$.

\begin{tabular}{|c|c|c|c|c|c|}
\hline \multicolumn{2}{|r|}{4} & \multicolumn{2}{|r|}{6} & \multicolumn{2}{|c|}{7} \\
\hline $\mathrm{Pt}(1)-\mathrm{C}(2)$ & $1.971(3)$ & $\operatorname{Pt}(1)-C(2)$ & $2.006(5)$ & $\mathrm{Pt}(1)-\mathrm{C}(2)$ & $2.021(3)$ \\
\hline $\mathrm{Pt}(1)-\mathrm{N}(1)$ & $2.014(2)$ & $\operatorname{Pt}(1)-N(1)$ & $2.058(4)$ & $\operatorname{Pt}(1)-N(1)$ & $2.203(3)$ \\
\hline $\mathrm{Pt}(1)-\mathrm{O}(1)$ & $2.0881(19)$ & $\operatorname{Pt}(1)-S(1)$ & $2.3197(8)$ & $\mathrm{Pt}(1)-\mathrm{C}(31)$ & $2.097(4)$ \\
\hline \multirow[t]{3}{*}{$\mathrm{Pt}(1)-\mathrm{O}(2)$} & $1.9982(19)$ & $\operatorname{Pt}(1)-S(2)$ & $2.2802(14)$ & $\mathrm{Pt}(1)-\mathrm{C}(32)$ & $2.073(4)$ \\
\hline & & & & $\operatorname{Pt}(1)-P(1)$ & $2.4373(10)$ \\
\hline & & & & $\operatorname{Pt}(1)-1(1)$ & $2.7681(3)$ \\
\hline$C(2)-P t(1)-N(1)$ & $80.77(10)$ & $C(2)-P t(1)-N(1)$ & $79.58(18)$ & $C(2)-P t(1)-N(1)$ & 79.15(14) \\
\hline $\mathrm{O}(1)-\mathrm{Pt}(1)-\mathrm{O}(2)$ & $90.62(8)$ & $S(1)-P t(1)-S(2)$ & $74.39(5)$ & $C(2)-P t(1)-C(31)$ & $86.11(16)$ \\
\hline$C(2)-P t(1)-O(2)$ & $91.46(10)$ & $C(2)-P t(1)-S(2)$ & $99.07(15)$ & $C(2)-P t(1)-C(32)$ & $92.06(15)$ \\
\hline \multirow[t]{9}{*}{$\mathrm{N}(1)-\operatorname{Pt}(1)-\mathrm{O}(1)$} & $97.12(8)$ & $N(1)-P t(1)-S(1)$ & $107.08(11)$ & $C(2)-P t(1)-P(1)$ & $90.85(10)$ \\
\hline & & & & $N(1)-P t(1)-P(1)$ & $90.88(8)$ \\
\hline & & & & $N(1)-\operatorname{Pt}(1)-I(1)$ & $100.96(8)$ \\
\hline & & & & $P(1)-P t(1)-I(1)$ & $93.60(2)$ \\
\hline & & & & $C(31)-P t(1)-I(1)$ & $89.44(12)$ \\
\hline & & & & $\mathrm{C}(31)-\mathrm{Pt}(1)-\mathrm{N}(1)$ & $88.31(16)$ \\
\hline & & & & $C(32)-P t(1)-P(1)$ & $94.22(13)$ \\
\hline & & & & $C(32)-\operatorname{Pt}(1)-C(31)$ & $86.15(18)$ \\
\hline & & & & $C(32)-\operatorname{Pt}(1)-I(1)$ & $87.42(11)$ \\
\hline
\end{tabular}

The $\mathrm{Pt}-\mathrm{N}$ and $\mathrm{Pt}-\mathrm{C}_{\mathrm{per}}$ bond lengths are significantly longer in the $\mathrm{Pt}^{\mathrm{IV}}$ compound $\mathbf{7}$ than in the $\mathrm{Pt}{ }^{\mathrm{II}}$ compounds $\mathbf{3}$ and $\mathbf{6}$. The methyl groups have different distances Pt(1)-C(31) 2.097(4) $\AA$ and Pt(1)$C(32) 2.073(4) \AA$ due to the larger trans influence of phosphine compared to $\mathrm{N}$-donor ligand. ${ }^{15}$ The $\mathrm{Pt}-\mathrm{I}$ bond length is 2.7681 (3) $\AA$, somewhat larger than those found in other similar metallacycles involving benzene derivatives with platinum, ${ }^{15}$ reflecting the high trans influence of the perylenyl group.

\section{Photophysical Studies}

a)UV-Vis absorption spectra. The UV-Vis absorption and emission spectra of dilute solutions in chloroform $\left(c \sim 10^{-5} \mathrm{M}\right)$ of the platinum complexes are summarized in Table 2 . On the other hand, the absorption spectra of the perylene imine are compared with those of complexes 2-9 in Fig. 3 to illustrate the influence of the $P t L_{n}$ group on the photophysical properties of the perylene imine.

All the spectra display a very intense band in the UV region at 250-300 nm (not shown in the figure). At higher wavenumbers, the visible absorption of the perylene imine is a band with vibronic structure covering the range $400-500 \mathrm{~nm}$ and red-shifted by about $1800 \mathrm{~cm}^{-1}$ compared to perylene. This vibronic structure, with a vibrational spacing of $\sim 1200 \mathrm{~cm}^{-1}$, is related to the stretching $v(C=C)$ frequency of the polyaromatic system and has increasing intensity of the vibronic bands for the higher $\lambda$ value.

The visible absorption spectra of the Pt" complexes 2-6 (Fig. 3A) are different in that two absorption bands with vibronic structure are observed: one at 380-500 $\mathrm{nm}$ with increasing intensity of the vibronic bands for higher $\lambda$ values; and another at 500-630 nm with decreasing intensity of the vibronic bands for higher $\lambda$ values. Considering their similarity to the spectral absorption patterns of the five-membered palladacyclic complexes previously reported, ${ }^{6 \mathrm{~b}}$ with less intensity for the observable maxima at lower energy, and the red shifted values observed for the similar palladium(II) complexes, the lower energy absorption bands are tentatively assigned to HOMO $\rightarrow$ LUMO transitions. The new absorption bands at 380-500 nm, hardly observed for the palladium complexes (Fig. 3C) should be assigned to the platinum complexation effect. It can be noted that the relative intensity and the vibronic structure is similar to that of perylene, with increasing intensity of the vibronic bands when moving to higher $\lambda$ values. Moreover, for complexes 5 (with $\mathrm{S}_{2} \mathrm{COMe}$ ) and $\mathbf{6}$ (with $\mathrm{S}_{2} \mathrm{CNEt}_{2}$ ), with S-donor ligands attached to $\mathrm{Pt}$, these bands are more intense than the low-energy bands at $500-630 \mathrm{~nm}$, and show a clear dependence on the ligands bonded to platinum. These low energy bands show very small solvent dependence. For example, when the solvent is changed from acetonitrile to toluene, the lowest energy bands of $\mathbf{4}$ are red-shifted by less than $400 \mathrm{~cm}^{-1}$ (see Fig. S1 in the ESIt). It is worth noting also the different red shift: $283 \mathrm{~cm}^{-1}$ for the lower energy and $373 \mathrm{~cm}^{-1}$ for the higher energy band. This behaviour suggests that these bands are most probably intraligand $\pi-\pi *$ transitions, or charge transfers not very solvent sensitive because of similar $\pi$ and $\pi^{*}$ charge distributions in the molecule. The origin of these bands is considered in more detail below, with the aid of TD-DFT calculations. 
Table 2 UV-Visible absorption and emission data for perylene imine (1) and their platinum complexes 2-9, in chloroform at $298 \mathrm{~K}$.

\begin{tabular}{|c|c|c|c|c|c|}
\hline Comp. & $\lambda(\mathrm{nm})\left(10^{-3} \varepsilon\right) / \mathrm{dm}^{3} \mathrm{~mol}^{-1} \mathrm{~cm}^{-1}$ & $\lambda_{\mathrm{ex}} / \mathrm{nm}$ & $\lambda_{\mathrm{em}} / \mathrm{nm}$ & $\Phi_{\mathrm{fl}}(\%)^{a}$ & $\tau^{b} / \mathrm{ns}$ \\
\hline 1 & $\begin{array}{l}243(34.5), 263(51.6), 425 \text { (17), } 449 \text { (33.8), } \\
477(33.8)\end{array}$ & 447 & 510 & $13^{c}$ & 5.3 \\
\hline 2 & $\begin{array}{l}246(51.6), 266(38.1), 434(15.0), 460 \text { (15.6), } \\
510(20.0), 529(18.8)\end{array}$ & 446,461 & 479,506 & $0.053^{c}$ & $2.5(73.0) 0.04(27.0)$ \\
\hline 3 & $\begin{array}{l}251 \text { (64.9), } 274(48.9), 401(12.6), 420(18.5), \\
444 \text { (23.7), } 468(25.0), 536(29.5), 566(25.2)\end{array}$ & 417,441 & 454,476 & $1.2^{c}$ & $2.1(13.0) 4.0(87.0)$ \\
\hline 4 & $\begin{array}{l}252 \text { (39.9), } 266 \text { (37.6), } 396 \text { (7.0), } 419 \text { (12.0), } \\
442 \text { (16.1), } 466 \text { (19.8), } 534 \text { (21.5), } 566 \text { (18.1 }\end{array}$ & $\begin{array}{l}427,452 \\
477\end{array}$ & $\begin{array}{l}517,549 \text { sh } \\
592\end{array}$ & $0.25^{c}$ & $2.3(5.0) 5.0(95.0)$ \\
\hline 5 & $\begin{array}{l}238(54.5), 274(32.0), 322(15.4), 436(13.4), \\
458(17.2), 485(20.3), 559(14.3), 593(10.8)\end{array}$ & $\begin{array}{l}426,449 \\
466\end{array}$ & 521,557 & $0.56^{c}$ & $1.2(9.3) 5.1(90.7)$ \\
\hline 6 & $\begin{array}{l}250(48.2), 278(38.2), 412(8.9), 436(17.2) \\
456(26.6), 484(28.3), 556(13.8), 592(12.0)\end{array}$ & 457,472 & $517,552 \mathrm{sh}$ & $0.78^{c}$ & $1.9(5.6) 5.1(94.4)$ \\
\hline 7 & $\begin{array}{l}239(80.4), 266(45.9), 357(6.9), 404(6.5) \\
458(19.2), 484(32.4), 513(34.8)\end{array}$ & 480,512 & $543,575 \mathrm{sh}$ & $3.9^{d}$ & $0.2(93.7) 4.1(6.3)$ \\
\hline 8 & $\begin{array}{l}240 \text { (57.7), } 268 \text { (42.4), } 358 \text { (8.9), } 405 \text { (5.9), } \\
473 \text { (14.9), } 506 \text { (27. 2), } 534(30.4)\end{array}$ & 505,536 & 573,612 sh & $29.1^{e}$ & $1.5(98.6) 3.8(1.4)$ \\
\hline 9 & $\begin{array}{l}246(58.6), 268(50.0), 345(14.1), 478(15.0) \text {, } \\
506(22.8), 536(24.8)\end{array}$ & 506,536 & 574,613 sh & $17.6^{e}$ & $0.8(90.7) 4.8(9.3)$ \\
\hline
\end{tabular}

${ }^{a}$ Quantum Yield. ${ }^{b}$ Fluorescence lifetimes. The percentage of each component is shown in parentheses. ${ }^{c}$ Determined in chloroform relative to perylene in ethanol $\left(\Phi_{\mathrm{fl}}=0.92\right)$ and using an excitation wavelength of $434 \mathrm{~nm}$. ${ }^{d}$ Determined in chloroform using Rhodamine $B$ in ethanol $\left(\Phi_{\mathrm{fl}}=0.70\right)$ and using an excitation wavelength of $510 \mathrm{~nm}$ ). ${ }^{e}$ Determined in chloroform relative to cresyl violet in ethanol $\left(\Phi_{\mathrm{fl}}=0.54\right)$ and using an excitation wavelength of $540 \mathrm{~nm}$. 

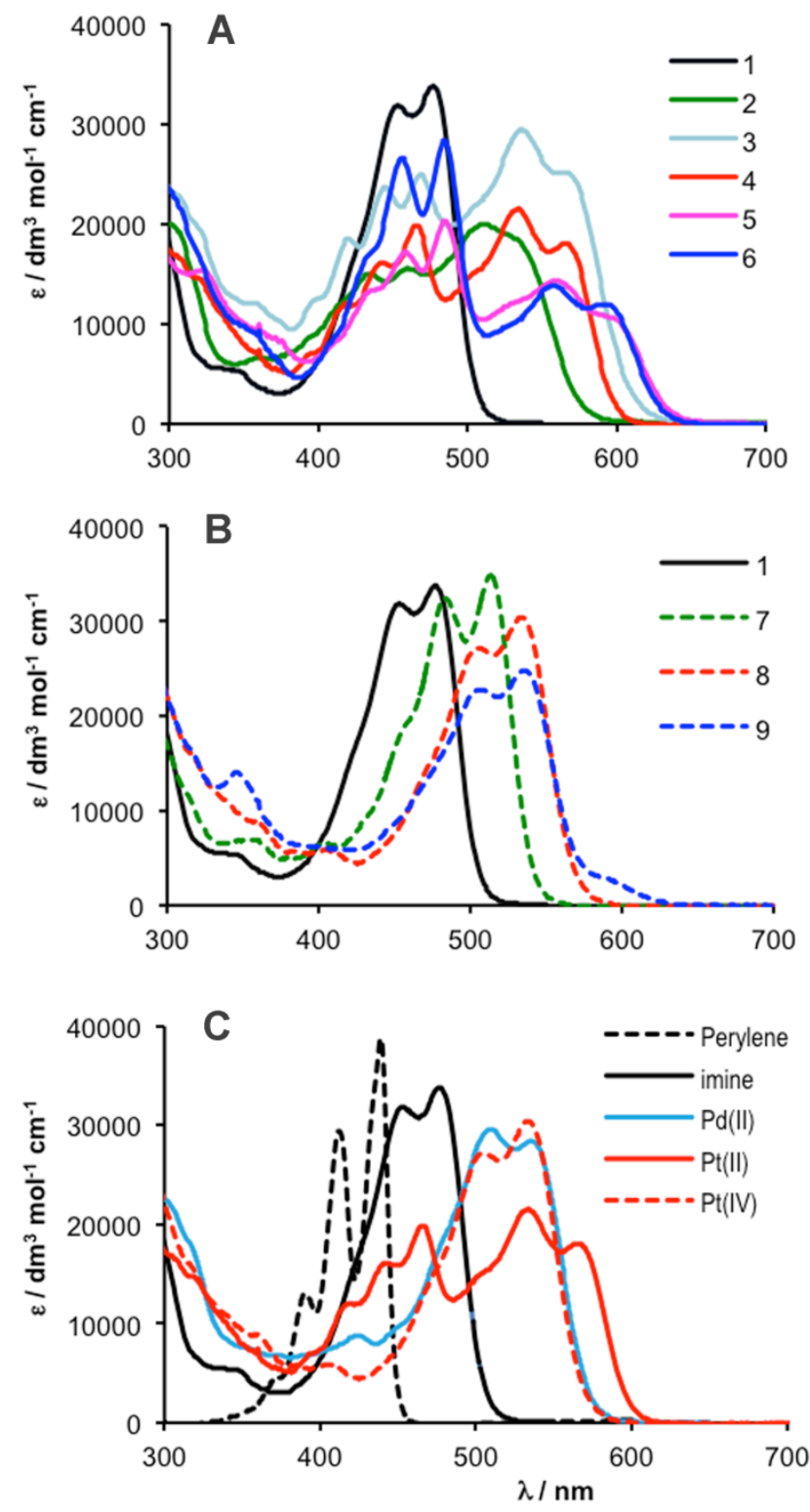

Fig. 3 Absorption spectra recorded in $\mathrm{CHCl}_{3}$ solution $\left(\sim 10^{-5} \mathrm{M}\right)$ at room temperature: A) Perylene imine (1) and their $\mathrm{Pt}$ " complexes complexes 2-6; B) Perylene imine and their $\mathrm{Pt}^{\mathrm{IV}}$ complexes 7-9; C) Comparison plot: Perylene; Perylene imine $1 ; \operatorname{Pd}(I I)=$ $\left[\mathrm{Pd}\left(\mathrm{C}^{\wedge} \mathrm{N}\right)(\mathrm{acac})\right] ;^{6 \mathrm{~b}} \mathrm{Pt}(\mathrm{II})=\left[\mathrm{Pt}\left(\mathrm{C}^{\wedge} \mathrm{N}\right)(\mathrm{acac})\right](4)$; and $\mathrm{Pt}(\mathrm{IV})=$ $\left[\mathrm{Pt}\left(\mathrm{C}^{\wedge} \mathrm{N}\right)(\mathrm{acac}) \mathrm{Mel}\right](\mathbf{8})$.

The spectral perturbation produced by interaction of the $\mathrm{Pt}^{\mathrm{IV}}$ group with the perylene imine orbitals (Fig. $3 \mathrm{~B}$ ) is quite different from that produced by Pt" group (Fig. 3A), and remarkably similar to the visible spectra observed for the palladium(II) complexes (Fig. $3 \mathrm{C})$. The red-shift of the complexes (relative to the perylene imine) observed for Pt", shows the order $2 \mathrm{Me} / \mathrm{PPh}_{3}\left(2060 \mathrm{~cm}^{-1}\right)<3 \mathrm{Cl} / \mathrm{Cl}$ $\left(3300 \mathrm{~cm}^{-1}\right) \sim 4$ acac $<6$ carbamate $\left(4070 \mathrm{~cm}^{-1}\right)<5$ xanthate $(4100$ $\left.\mathrm{cm}^{-1}\right)$. These red-shifts are larger than in the case of the analogue five-membered Pd" complexes $\left(2270-2615 \mathrm{~cm}^{-1}\right)$, and the influence of the ligands on $\mathrm{Pt}^{\prime \prime}$ is somewhat larger than found in $\mathrm{Pd}^{\mathrm{II}}$.

Comparing the UV-Vis spectra of 7, 8 and $\mathbf{9}$ (Fig. 3B) with 2, 4 and 6 (Fig. $3 \mathrm{~A}$ ), shows that the change of oxidation state of the $\mathrm{Pt}$ center largely influences the absorption spectra of the complexes. This is clearly seen in Fig. 3C, which depicts the room temperature absorption spectra in $\mathrm{CHCl}_{3}$ of perylene, perylene imine (1) and their complexes $\left[\mathrm{Pd}\left(\mathrm{C}^{\wedge} \mathrm{N}\right)(\mathrm{acac})\right],{ }^{6 \mathrm{~b}}\left[\mathrm{Pt}\left(\mathrm{C}^{\wedge} \mathrm{N}\right)(\mathrm{acac})\right](4)$ $\left[\mathrm{Pt}\left(\mathrm{C}^{\wedge} \mathrm{N}\right)(\mathrm{acac}) \mathrm{Mel}\right](8)$, which are the cases studied below by TDDFT. Smaller bathocromic shifts are observed for the absorption maxima in $\mathrm{Pt}^{\mathrm{IV}}$ derivatives relative to the perylene imine than those found for Pt": $1470 \mathrm{~cm}^{-1}$ for $\mathbf{7}<2060 \mathrm{~cm}^{-1}$ for $\mathbf{2}$ in the $\mathrm{Me} / \mathrm{PPh}_{3}$ complexes; $2240 \mathrm{~cm}^{-1}$ for $8<3300 \mathrm{~cm}^{-1}$ for 4 in the acac derivatives; $2310 \mathrm{~cm}^{-1}$ for $9<4070 \mathrm{~cm}^{-1}$ for 6 in the carbamate derivatives. This is the expected result, as a higher oxidation state should contract the $d$ orbitals of Pt and reduce the magnitude of the overlap with the perylene orbitals.

\section{Molecular orbital calculations}

TD-DFT calculations were performed on representative perylene imine derivatives to assign the orbitals involved in the electronic transitions observed in the absorption spectra. The ligand perylene imine $\mathrm{HC}^{\wedge} \mathrm{N}=3-\mathrm{C}_{20} \mathrm{H}_{11} \mathrm{CH}=\mathrm{NC}_{6} \mathrm{H}_{4}-p-\mathrm{C}_{2} \mathrm{H}_{5}(\mathbf{1})$ and the complexes $\left[\mathrm{M}\left(\mathrm{C}^{\wedge} \mathrm{N}\right)(\mathrm{acac})\right](\mathrm{M}=\mathrm{Pd}, \mathrm{Pt}(\mathbf{4})),\left[\mathrm{Pt}\left(\mathrm{C}^{\wedge} \mathrm{N}\right)(\mathrm{acac}) \mathrm{Mel}\right](\mathbf{8})$ were calculated. The calculated values for distances and angles match fairly well the corresponding experimental values determined in the $X$-ray structure of $\mathbf{4}$ and in other related cyclometallated and acac derivatives of $\mathrm{Pd}$ and $\mathrm{Pt}$.

The absorption spectra were calculated by TD-DFT in the gas phase and in chloroform. Fig. 4 displays a correlation diagram showing the energy and the atomic orbital composition of the MOs in the main calculated transition for the corresponding absorption spectra. The lowest energy transition for perylene imine (1) in chloroform solution corresponds to HOMO $\rightarrow$ LUMO transition at $506 \mathrm{~nm}(f=0.95)$. These two orbitals are centered in the perylene $\pi$-system ( 86 and $79 \%$, respectively), as shown in Fig. 4. A second band, related to the perylene system (not represented in Fig. 4), with lower intensity than the former, is expected about $265 \mathrm{~nm}$ and is assigned to a combination of several transitions between the HOMO and higher empty $\pi^{*}$ orbitals of perylene. In our previous publications we have also found these two absorptions, which are characteristic of the perylene derivatives, ${ }^{4-6}$ at experimental values of 477 and $263 \mathrm{~nm}$. Since the involved orbitals are centered in the perylene fragment, the wavelength values associated with this absorptions are very similar for the ligand and complexes. 
Table 3 Calculated absorption parameters (wavelengths in $\mathrm{nm}$ and their intensities) for the perylene imine compounds in chloroform solution. ${ }^{\mathrm{a}}$

\begin{tabular}{ccccc}
\hline Assignation & Perylene imine & {$\left[\mathrm{Pd}^{\prime \prime}\left(\mathrm{C}^{\wedge} \mathrm{N}\right)(\mathrm{acac})\right]$} & {$\left[\mathrm{Pt}^{\prime \prime}\left(\mathrm{C}^{\wedge} \mathrm{N}\right)(\mathrm{acac})\right]$} & {$\left[\mathrm{Pt}^{\mathrm{IV}}\left(\mathrm{C}^{\wedge} \mathrm{N}\right)(\mathrm{acac}) \mathrm{Mel}\right]$} \\
\hline Perylene: & $506(0.95)$ & $545(0.76)$ & $553(0.67)$ & $547(0.72)$ \\
$\pi($ Per $) \rightarrow \pi^{*}($ Per $)$ & $302(0.12)$ & $286(0.09)$ & $289(0.14)$ & $324(0.06)$ \\
& $267(0.27)$ & $271(0.19)$ & $272(0.18)$ & $269(0.09)$ \\
& $261(0.09)$ & $263(0.09)$ & $265(0.07)$ & \\
\hline $\mathrm{LLCT}:$ & - & $423(0.07)$ & $441(0.14)$ & $388(0.05)$ \\
$\pi(\mathrm{acac}) \rightarrow \pi^{*}($ Per $)$ & & & & \\
\hline $\mathrm{ILCT}:$ & $394(0.04)$ & $356(0.10)$ & $353(0.13)$ & \\
$\pi(\mathrm{Ar}) \rightarrow \pi^{*}($ Per $)$ & $294(0.21)$ & & & \\
\hline
\end{tabular}

${ }^{a}$ A complete assignement of the absorption spectra parameters is available from ESI. LLCT = ligand-to-ligand charge-transfer. ILCT = interligand charge-transfer from aryl group to perylene.

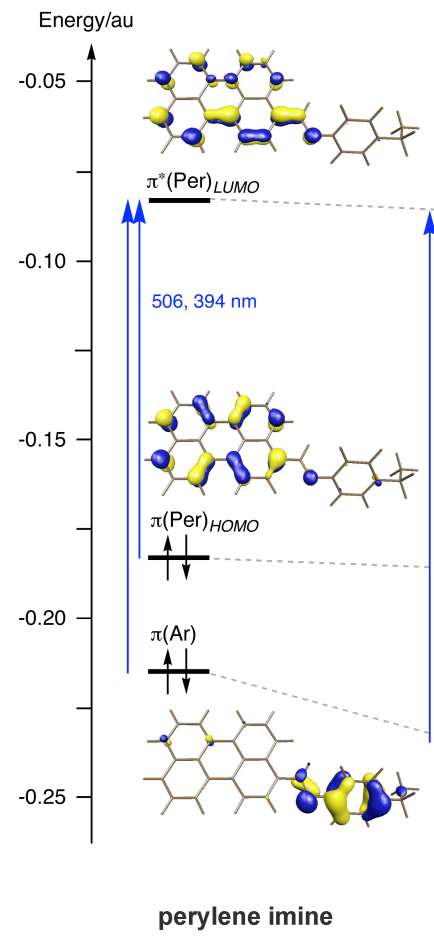

$\mathrm{HC}^{\wedge} \mathrm{N}$

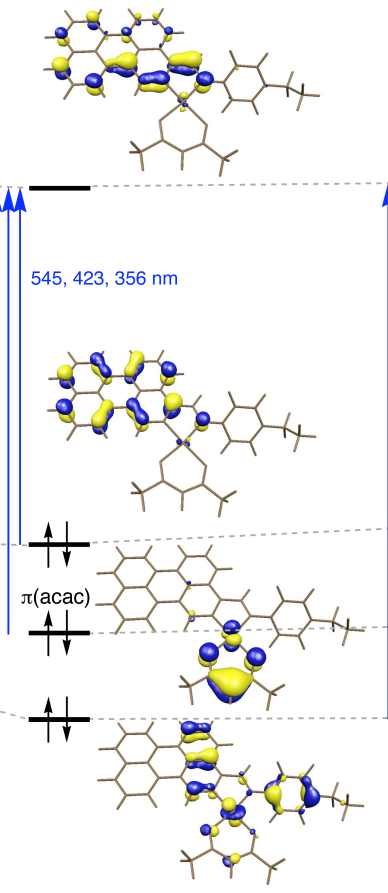

$\left[P d\left(C^{\wedge} N\right)(a c a c)\right]$

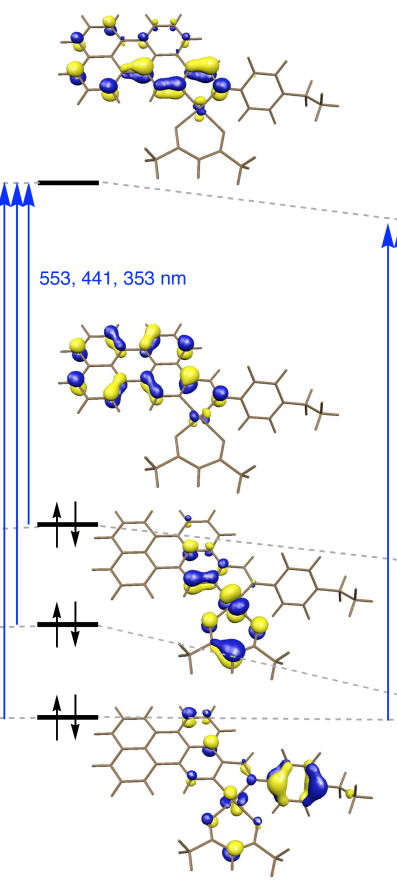

$\left[\mathrm{Pt}\left(\mathrm{C}^{\wedge} \mathrm{N}\right)(\mathrm{acac})\right]$

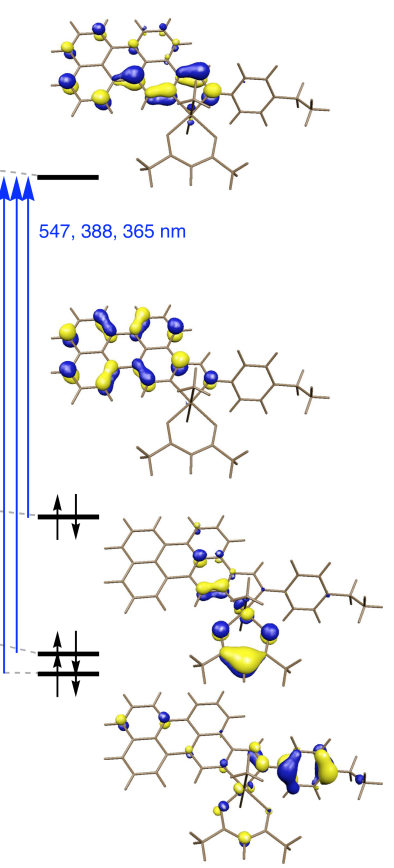

$\left[\mathrm{Pt}\left(\mathrm{C}^{\wedge} \mathrm{N}\right)(\mathrm{acac}) \mathrm{Mel}\right]$

Fig. 4 Schematic representation of main expected transition in the absorption spectra of the perylene imine compounds.

Related results are obtained for the transitions and orbitals for the complexes containing perylene imine $\left[M\left(C^{\wedge} N\right)(a c a c)\right](M=P d$, $\mathrm{Pt}$ ) (see Fig. 4). The lower energy absorptions correspond to the HOMO $\rightarrow$ LUMO transition and are calculated to appear at 545 and $553 \mathrm{~nm}$, respectively, in satisfactory concordance with the experimental values at 535 and $566 \mathrm{~nm}$. The most energetic bands of the perylene are predicted in the range 272 and $262 \mathrm{~nm}$ together one ligand-to-metal chargue transfer (LMCT) band about $260 \mathrm{~nm}$ (Per $\rightarrow \mathrm{d} x^{2}-y^{2}$ ) (see Table S1). The intensity of the lower energy band decreases due to the orbital modification in the LUMO by the coordination to $\mathrm{Pd}$ or $\mathrm{Pt}$, since the perylene contribution decreases (from $86 \%$ in the ligand to $64 \%$ in the Pd complex and $67 \%$ in the Pt complex), and the imine fragment contribution increases (from $5 \%$ to $20-19 \%$ ). Since no significant changes are 
observed in other perylene orbitals, alterations in the second band are not expected. Experimentally, these bands are reasonably well reproduced at 273 and $266 \mathrm{~nm}$ for $\mathrm{Pd}^{\prime \prime}$, ${ }^{6 \mathrm{~b}}$ and $\mathrm{Pt}$ ", respectively.

Perylene imine complexes have also an intraligand chargetransfer (ILCT) from the ethylphenyl substituent to the perylene system at $356(f=0.10)$ and $353(f=0.13) \mathrm{nm}$ for Pd" and Pt", respectively. This monoexcitation involves an occupied orbital centered in ethylphenyl group having significant contribution of the perylene ( $35 \%$ for Pd, $24 \%$ for Pt). It has been calculated at $394 \mathrm{~nm}$ $(f=0.04$ ) before metallation of the peryleneimine, but its expected intensity is very low due to the poor contribution of perylene $(13 \%)$, whereas the most intense $\mathrm{Ar} \rightarrow$ Per excitation at $294 \mathrm{~nm}(f=$ 0.21 ) implies another higher MO of perylene. As shown in Fig. 4 and Table 2, a new absorption band appears having ligand-to-ligand charge-transfer (LLCT) character from acetylacetonate to perylene at $423(f=0.07)$ and $441(f=0.14) \mathrm{nm}$ for Pd" and Pt", respectively. Although this molecular orbital is centered in the acetylacetonato ligand (71\%), it also has a low contrubution of Pd (20\%) and perylene (8\%). This changes drastically for $\mathrm{Pt}^{\prime \prime}$, in which identical contributions are found for acetylacetonato, $\mathrm{Pt}$ and perylene (30\%). In this case, the transition is favoured by the larger localization on the perylene, mainly in the $\mathrm{C}=\mathrm{C}$ bond contiguous to metallated position. The larger intensities of that band for Pt" than for Pd" complexes explain the important differences observed in the experimental spectra.

The oxidation of $\mathrm{Pt}^{\mathrm{I}}$ complex to $\mathrm{Pt}^{\mathrm{IV}}$ with Mel provides important changes in the predicted spectra. Complex

$\left[\mathrm{Pt}\left(\mathrm{C}^{\wedge} \mathrm{N}\right)(\mathrm{acac}) \mathrm{Mel}\right](4)$ has HOMO $\rightarrow$ LUMO and $\pi(\mathrm{Per}) \rightarrow \pi^{*}($ Per $)$ transitions at $547 \mathrm{~nm}(f=0.72)$, with lower red shift than $\mathrm{Pt}^{\prime \prime}$, and at 286-261 nm, following the trends observed in previous Pd" or Pt" compounds. Moreover, the ILCT $\pi(\mathrm{Ar}) \rightarrow \pi^{*}(\mathrm{Per})$ band appears at $365 \mathrm{~nm}(f=0.13)$, without notable changes in percentage participations of the metal upon oxidation from $\mathrm{Pt}^{\mathrm{II}}$ to $\mathrm{Pt}^{\mathrm{IV}}$ (24 and $22 \%$, respectively). However, the oxidation of platinum stabilizes the molecular orbital centered in the acetylacetonate ligand and induces a dramatic change in this transition, predicted at $388 \mathrm{~nm}$. This blue shift displacement is accompanied by a decrease in intensity $(f=0.05)$, according with low contribution of the perylene (24\%). This calculated value is also in agreement with the weak absorption observed at $\sim 400 \mathrm{~nm}$ in the UV-Vis absorption spectrum (Fig. 3B).

\section{(b) Luminescence spectra}

Luminescence spectra of the perylene imine 1 ligand and the platinum complexes 2-9 at room temperature in chloroform are listed in Table 2. All complexes exhibit fluorescence in solution (which is unusual for cyclometallated Pt complexes) and display emission bands with some defined vibronic structure in the range 450-700 nm (see Fig. 5), which can be correlated to those well defined for perylene at about $425-525 \mathrm{~nm}$ and scarcely defined for imine at about 450-625 nm. This vibronic structure, with a vibrational spacing of $\sim 1200 \mathrm{~cm}^{-1}$, is related to the stretching $v(C=C)$ frequency of the polyaromatic system and demonstrates the involvement of ligand character in their emission origin.
The emission properties are nearly unaffected in the presence of $\mathrm{O}_{2}$, which is characteristic of fluorescence emission. ${ }^{23}$ Despite the presence of the Pt atom, no phosphorescence can be detected for the complexes even at $77 \mathrm{~K}$. For example, the spectrum of $\mathbf{4}$, in frozen Me-THF, shows no additional emission bands and the shoulders are resolved as peaks (See Fig. S2-S3 in ESI).

On the basis of the similar Stokes shifts between absorption and emission (less than $2200 \mathrm{~cm}^{-1}$ in all cases) the luminescence observed can be assigned to $\pi-\pi^{*}$ fluorescence. ${ }^{23}$ This was further confirmed by their emission lifetimes, in the range $0.2-5.0 \mathrm{~ns}$ (Table 2). Similar to analogous $\mathrm{Pd}^{\prime \prime}$ compounds, the $\mathrm{Pt}^{\text {"I }}$ and $\mathrm{Pt}^{\mathrm{IV}}$ complexes show biexponential decay with lower lifetimes than perylene imine, and longer for the $\mathrm{Pt}^{\mathrm{I}}$ than for the $\mathrm{Pt}^{\mathrm{IV}}$ compounds.

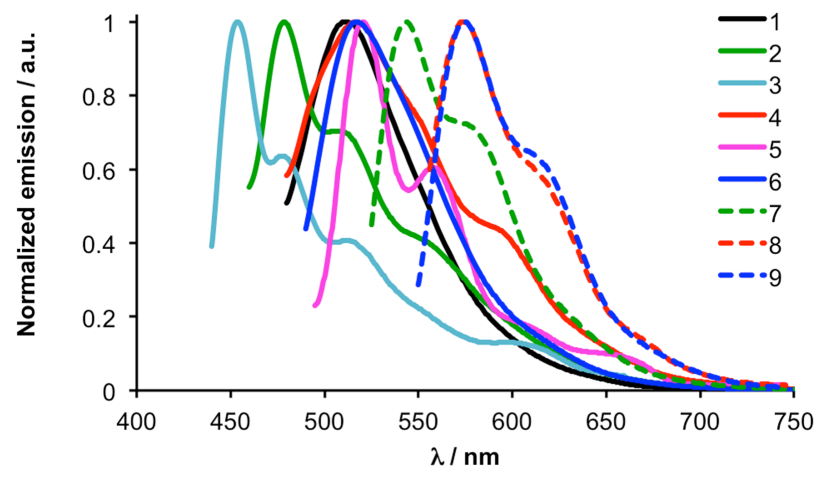

Fig. 5 Emission spectra recorded in $\mathrm{CHCl}_{3}$ solution $\left(10^{-5} \mathrm{M}\right)$ at room temperature of perylene imine (1), their Pt" complexes $2-6$, and their Pt ${ }^{\mathrm{IV}}$ complexes $\mathbf{7 - 9}$.

When excited at the wavelength corresponding in each case to the band previous to the lower energy band, all Pt" compounds emit weakly in the visible region at $298 \mathrm{~K}$. In contrast to the analogous Pd" complexes, the emission spectra of the Pt" compound present a band about $450-520 \mathrm{~nm}$, slightly more structured than that in the perylene imine ligand and absent in the $\mathrm{Pd}^{\prime \prime}$ analogous (see Fig. 5). Since our calculations suggest that monoexcitations are available, from several occupied orbitals to $\pi^{*}$ (Per)-LUMO, this weak emission should be associated to a deexcitation from the LUMO to the $\pi$ (acac). Comparing the topology of the two orbitals involved, the different contributions of perylene in $\pi$ (acac) favours that only Pt" compound present this band. Also, another very weak band at $\lambda \approx 610 \mathrm{~nm}$ can be observed, more clearly for complex $\mathbf{3}$, in the expected position relative to perylene imine, observed for the palladium analogues.

As shown in Fig. 5, the emission bands of $\mathrm{Pt}^{\mathrm{IV}}$ complexes 7-9 show some evidence of vibrational structure, more structured than for the free perylene imine, and also the influence of the ligands on the photophysical properties of metal complexes. Thus, a notable red-shift is observed relative to the perylene imine of $1190 \mathrm{~cm}^{-1}$ for $7,2160 \mathrm{~cm}^{-1}$ for 8 and $2190 \mathrm{~cm}^{-1}$ for $\mathbf{9}$, in concordance with the red shift observed in their absorption spectra relative to the perylene imine. 
The emission quantum yields, $\Phi_{\mathrm{fl}}$, of the platinum complexes $\mathbf{2}$ 9 were measured in chloroform at room temperature. Our recorded luminescence quantum yield of 0.13 for the perylene imine ligand suffers a notable reduction in emission intensity compared to perylene $\left(\Phi_{\mathrm{fl}}=0.92\right),{ }^{24}$ probably because the fluorescence of the perylene moiety is quenched by a photoinduced intramolecular electron transfer (PET) process. ${ }^{25}$ The Pt complexes are only weakly fluorescent $\left(\Phi_{\mathrm{fl}}\right.$ in the range $5.310^{-4}$ $-1.210^{-2}$ ) showing a marked detrimental metal center effect ( 1 or 2 orders of magnitude lower) when compared with the analogues $\mathrm{Pd}^{\prime \prime}$ complexes $\left(\Phi_{\mathrm{fl}}\right.$ in the range $\left.0.01-0.08\right)$. Surprisingly, in the complexes of $\mathrm{Pt}^{\mathrm{IV}}$ an important fluorescence enhancement is observed, to $\Phi_{\mathrm{fl}}$ in the range $0.039-0.291$, and compounds 7-9 are more than 2 orders of magnitude more intensely emissive in aerated chloroform solution at room temperature than the $\mathrm{Pt}$ ", and 2-3 times more emissive than the $\mathrm{Pd}^{\prime \prime}$ complexes with perylene imine (Table 2). Moreover, the fluorescence quantum yield is enhanced in the complexes $\mathbf{8}$ and $\mathbf{9}$ compared with the perylene imine ligand, suggesting an attenuation of the quenching associated to the imine group. As it is to be expected and as supported by the ${ }^{195} \mathrm{Pt}$ chemical shifts, $\mathrm{Pt}{ }^{\mathrm{IV}}$ is a stronger electron acceptor than $\mathrm{Pt}$ ": The ${ }^{195} \mathrm{Pt}$ resonances at $\delta=-2392 \mathrm{ppm}$ for $\mathbf{8}$, $3189 \mathrm{ppm}$ for $\mathbf{9}$, and -3345 ppm for $\mathbf{7}$ support the increase in electron density on platinum in the order $\mathbf{8}<\mathbf{9}<\mathbf{7}$. Consequently it will be more effective for polarizing the imine electron density towards the $\mathrm{Pt}^{\mathrm{IV}}$ center, thus reducing the PET quenching effect and restoring a higher fluorescence intensity. The lower participation, found in our calculations, of the metal d orbitals in the HOMO and LUMO in $\mathrm{Pt}^{\mathrm{IV}}$ compared to $\mathrm{Pt}^{\mathrm{I}}$ also might also contribute to attenuate the influence of spin-orbit coupling associated to the heavy atom effect of $\mathrm{Pt}^{26}$

The differences in fluorescence intensity observed for Pt" and $\mathrm{Pt}^{\mathrm{IV}}$ in our complexes are in contrast with opposite results reported for dansyl ethylenediamine complexes (with long distance of the dansyl fluorophore from the Pt center), ${ }^{27}$ or for 7-amino-4methylcoumarin cmplexes (with the Pt center near to fluorophore), ${ }^{28}$ where the emission quantum yields for $\mathrm{Pt}^{\mathrm{IV}}$ are significantly lower than for Pt", and both lower than those of the ligands. However, there are also related examples (with amine and perylene derivatives or other chromophores), where the existence of a metal prevents PET between the receptor and the fluorophore, and the emission of the system is enhanced. ${ }^{29}$

The differences in emission quantum yield when comparing 7 $\left(\Phi_{\mathrm{fl}}=0.039\right)$ with $\mathbf{8}\left(\Phi_{\mathrm{fl}}=0.29\right)$ and $\mathbf{9}\left(\Phi_{\mathrm{fl}}=0.18\right)$ are remarkable suggesting a notable and complex dependence on the different ligands and their distribution around the platinum, beyond the factors already commented. For instance, comparing $\mathbf{8}$ and $\mathbf{9}$, which only differ in the ancillary ligand (acac versus carbamate), the acac derivative is more luminescent. Also the donor ability of the ancillary ligands on the Pt fragment is expected to make an effect, since they influence differently the electron density of $\mathrm{Pt}^{\mathrm{IV}}$. In this respect, the order of the ${ }^{3} \mathrm{JPt}_{\mathrm{H}}$ coupling constants for the imine $\mathrm{H}$ atom is consistent with the decreasing trans-influence of the ligands leading to increasing strength the of $\mathrm{Pt}-\mathrm{N}$ bond: $44 \mathrm{~Hz}$, in 7
( $\mathrm{C}_{\text {methyl }}$ trans to $\mathrm{N}$ ); $90 \mathrm{~Hz}$, in $\mathbf{9}\left(\mathrm{S}_{\text {carbamate }}\right.$ trans to $\left.\mathrm{N}\right)$; $109 \mathrm{~Hz}$, in 8 $\left(\mathrm{O}_{\text {acac }}\right.$ trans to $\left.\mathrm{N}\right)$. In addition, the lower emission quantum yield for 7 might be related to the fact that the greater rigidity associated with the chelate versus monodentate ligands favours luminescence over non-radiative decay pathway. We have found lower efficiency in the cyclopalladate complexes with $\mathrm{Pd}^{\text {" bearing monodentate }}$ ligands (phosphine ligand), and complex 2 (bearing a phosphine ligand) exhibits the lowest emission quantum yield for the Pt" complexes described here.

\section{Conclusions}

The metallation of 3-perilenylmetilen-4'-ethylaniline with $\left[\mathrm{Pt}_{2} \mathrm{Me}_{4}\left(\mu-\mathrm{SMe}_{2}\right)_{2}\right]$ or $\left[\mathrm{Pt}_{2}(\mu-\mathrm{Cl})_{2}\left(\eta^{3}-\mathrm{C}_{4} \mathrm{H}_{7}\right)_{2}\right]$ shows selectivity for the ortho position with respect to the imine group yielding specifically a five-membered endo metallacycle, in contrast to palladium that presents preference for the peri position, giving six-membered metallacycles.

In solution at room temperature, the complexes of Pt" exhibit weak fluorescence associated to the perylene system, with lower emission quantum yields than the palladium analogues.

The oxidation with Mel of the complexes of $\mathrm{Pt}^{\mathrm{II}}$ to $\mathrm{Pt}^{\mathrm{IV}}$ reduces the electron-donating ability of the imine group towards perylene, thus suppressing the PET process and causing a remarkable enhancement in the emission intensity. The quantum yield of $\mathrm{Pt}^{\mathrm{IV}}$ complexes reaches $\Phi_{\mathrm{fl}}=0.29$ for $\mathbf{8}$, (over 100 times the value for Pt"). Phosphorescence, often observed for late organo-transition metal complexes, is not observed in our complexes.

\section{Experimental Section}

Materials and general methods. All reactions were carried out under dry nitrogen. The solvents were purified according to standard procedures. Literature methods were used to prepare $1,{ }^{6}$ $\left[\mathrm{Pt}_{2} \mathrm{Me}_{4}\left(\mu-\mathrm{SMe}_{2}\right)_{2}\right],{ }^{30}\left[\mathrm{Pt}_{2}(\mu-\mathrm{Cl})_{2}\left(\eta^{3}-\mathrm{C}_{4} \mathrm{H}_{7}\right)_{2}\right],{ }^{31}$ and $[\mathrm{TI}(\mathrm{acac})] .{ }^{32} \mathrm{C}, \mathrm{H}$, $\mathrm{N}$ analyses were carried out on a Perkin-Elmer 2400 microanalyzer. IR spectra $\left(\mathrm{cm}^{-1}\right)$ were recorded on a Perkin-Elmer FT-1720X spectrometer. ${ }^{1} \mathrm{H}$ NMR, ${ }^{31} \mathrm{P}$ NMR and ${ }^{195} \mathrm{Pt}$ NMR spectra were recorded on Bruker AC 300, Bruker AV $400 \mathrm{MHz}$ and Varian 500 spectrophotometers in $\mathrm{CDCl}_{3}$, with chemical shifts referred to TMS, $85 \% \mathrm{H}_{3} \mathrm{PO}_{4}$ and respectively. UV-vis absorption spectra were obtained on a Shimadzu UV-1603 spectrophotometer, in chloroform solution $\left(1 \times 10^{-5} \mathrm{M}\right)$. Luminescence data were recorded on a Perkin-Elmer LS-luminescence spectrometer, in $\mathrm{CHCl}_{3}\left(1 \times 10^{-5}\right.$ $\mathrm{M})$ and in solid state measurements were made using finely pulverized $\mathrm{KBr}$ dispersions of the sample in $5 \mathrm{~mm}$ quartz tubes at room temperature. Luminescence quantum yields were obtained at room temperature using the optically dilute method $(A<0.1)$ in degassed chloroform (quantum yields standard were perylene in methanol $\left(\Phi_{\mathrm{fl}}=0.92\right),{ }^{24}$ rhodamine $\mathrm{B}$ in ethanol $\left(\Phi_{\mathrm{fl}}=0.70\right),{ }^{33}$ and cresyl violet in ethanol $\left(\Phi_{\mathrm{fl}}=0.54\right)^{34}$ and using an excitation wavelength of 434,510 and $540 \mathrm{~nm}$, respectively $\mathrm{nm}$ ). The emission lifetime measurements were carried out with a Lifespecred picosecond fluorescence lifetime spectrometer from Edinburgh 
Instruments. As excitation sources two diode lasers, with 405 and $470 \mathrm{~nm}$ nominal wavelengths were used. The first wavelength (405 $\mathrm{nm}$ ) has a pulse width of $88.5 \mathrm{ps}$, with a typical average power of $0.40 \mathrm{~mW}$. The second wavelength $(470 \mathrm{~nm})$ has a pulse width of $97.2 \mathrm{ps}$, and its typical average power is $0.15 \mathrm{~mW}$. The pulse period is $1 \mu \mathrm{s}$ and the pulse repetition frequency is $10 \mathrm{MHz}$. The monocromator slit is $2 \mathrm{~nm}$. The instrument response measure at the HWHM (half width at half maximum) was below 350 ps. The technique used is "Time Correlated Single Photon Counting" (TCSPC).

Computational details. Unrestricted calculations were carried out using the Gaussian09 package. ${ }^{35}$ The hybrid density function method known as B3LYP was applied. ${ }^{36}$ Effective core potentials (ECP) were used to represent the innermost electrons of the transition atoms ( $\mathrm{Cr}, \mathrm{Mo}, \mathrm{W}$ and $\mathrm{Au})$ and the basis set of valence double-z quality for associated with the pseudopotentials known as LANL2DZ. ${ }^{37}$ The basis set for the main group elements was 6-31G* $(\mathrm{Br}, \mathrm{P}, \mathrm{C}, \mathrm{N}, \mathrm{F}$ and $\mathrm{H}) .^{38}$ Solvent effects of chloroform were taken into account by $\mathrm{PCM}$ calculations, ${ }^{39}$ keeping the geometry optimized for gas phase (single-point calculations). Excited states and absortion spectra were obtained from the time-depending algorithm implemented in Gaussian09. ${ }^{40}$

Preparation of 2. To a solution of 3-perilenylmetilen-4'-ethylaniline (1) $(0.136 \mathrm{mg}, 0.356 \mathrm{mmol})$ in dry toluene $(18 \mathrm{~mL})$ was added $\left[\mathrm{Pt}_{2} \mathrm{Me}_{4}\left(\mu-\mathrm{SMe}_{2}\right)_{2}\right](0.102 \mathrm{~g}, 0.178 \mathrm{mmol})$. After $16 \mathrm{~h}$ stirring $\mathrm{PPh}_{3}$ $(0.093 \mathrm{~g}, 0.356 \mathrm{mmol})$ was added and the mixture was stirred overnight. The solvent was evaporated to dryness and the red solid was washed with hexane $(2 \times 5 \mathrm{~mL})$ and diethyl ether $(3 \times 5 \mathrm{~mL})$. Yield: $0.260 \mathrm{~g}(86 \%)$. Anal. Calcd. for $\mathrm{C}_{48} \mathrm{H}_{38} \mathrm{NPPt}$ : C, 67.44; $\mathrm{H}, 4.48$; $\mathrm{N}, 1.64$. Found: $\mathrm{C}, 67.16 ; \mathrm{H}, 4.45 ; \mathrm{N}, 1.94 .{ }^{1} \mathrm{H}-\mathrm{RMN}(500 \mathrm{MHz}$, $\left.\mathrm{CDCl}_{3}\right): \delta 9.37\left(\mathrm{~s}^{3} \mathrm{~J}_{\mathrm{PtH}}=53.2 \mathrm{~Hz}, 1 \mathrm{H}, \mathrm{HC}=\mathrm{N}\right), 8.94\left(\mathrm{~d},{ }^{4} \mathrm{~J}_{\mathrm{PH}}=5.4 \mathrm{~Hz}\right.$, $\left.{ }^{3} \mathrm{JPtH}_{\mathrm{PtH}}=51.1 \mathrm{~Hz}, 1 \mathrm{H}, \mathrm{H}^{1}\right), 8.45(\mathrm{~d}, \mathrm{~J}=7.4 \mathrm{~Hz}, 1 \mathrm{H}), 8.22(\mathrm{~d}, \mathrm{~J}=7.5 \mathrm{~Hz}$, $1 \mathrm{H}), 8.14(\mathrm{~d}, \mathrm{~J}=7.4 \mathrm{~Hz}, 1 \mathrm{H}), 7.97(\mathrm{~d}, \mathrm{~J}=8.4 \mathrm{~Hz}, 1 \mathrm{H}), 7.70(\mathrm{~d}, \mathrm{~J}=8 \mathrm{~Hz}$, $1 \mathrm{H}), 7.69(\mathrm{~d}, \mathrm{~J}=8.2 \mathrm{~Hz}, 1 \mathrm{H}), 7.54(\mathrm{~m}, 6 \mathrm{H}), 7.49(\mathrm{td}, \mathrm{J}=7.8,3.0 \mathrm{~Hz}$, $2 \mathrm{H}), 7.43(\mathrm{t}, \mathrm{J}=7.9 \mathrm{~Hz}, 1 \mathrm{H}), 7.32(\mathrm{~m}, 3 \mathrm{H}), 7.28-7.23(\mathrm{~m}, 6 \mathrm{H}), 6.72$, $6.58\left(\mathrm{AA}^{\prime} \mathrm{BB}^{\prime}\right.$ system, $\left.\mathrm{J}=7.9 \mathrm{~Hz}, 4 \mathrm{H}\right), 2.45\left(\mathrm{q}, \mathrm{J}=7.6 \mathrm{~Hz}, 2 \mathrm{H}, \mathrm{CH}_{2} \mathrm{CH}_{3}\right.$ ), $1.14\left(\mathrm{~d},{ }^{3} \mathrm{JPH}_{\mathrm{PH}}=7.2 \mathrm{~Hz},{ }^{2} \mathrm{~J}_{\mathrm{PtH}}=51.1 \mathrm{~Hz}, 3 \mathrm{H}\right), 1.11(\mathrm{t}, \mathrm{J}=7.6 \mathrm{~Hz}, 3 \mathrm{H}$, $\left.\mathrm{CH}_{2} \mathrm{CH}_{3}\right) .{ }^{31} \mathrm{P}\left\{{ }^{1} \mathrm{H}\right\} \mathrm{RMN}\left(\mathrm{CDCl}_{3}, 202 \mathrm{MHz}\right): \delta 29.8\left(\mathrm{~s},{ }^{1} \mathrm{~J}_{\mathrm{PtP}}=2182 \mathrm{~Hz}\right)$. ${ }^{195} \mathrm{Pt} \mathrm{NMR}\left(\mathrm{CDCl}_{3}, 107 \mathrm{MHz}\right): \delta-4215\left(\mathrm{~d},{ }^{1} \mathrm{~J}_{\mathrm{PtP}}=2182 \mathrm{~Hz}\right)$. IR (KBr, $\left.\mathrm{cm}^{-1}\right): 1557 v(\mathrm{C}=\mathrm{N})$.

Preparation of 3. To a suspension of di- $\mu$-chlorobis $\left(\eta^{3}-2\right.$ methylallylplatinum) $(0.370 \mathrm{~g}, 0.65 \mathrm{mmol})$ in dry $\mathrm{MeOH}(5 \mathrm{~mL})$ under nitrogen was added 3-perilenylmetilen-4'-ethylaniline (1) $(0.500 \mathrm{~g}, 1.3 \mathrm{mmol})$, and the mixture was refluxed for $24 \mathrm{~h}$. After cooling, the black precipitate was collected on a frit, washed with methanol $(5 \mathrm{~mL})$ and acetone $(2 \times 5 \mathrm{~mL})$. Yield: $0.688 \mathrm{~g}(86 \%)$. Anal. Calcd. for $\mathrm{C}_{58} \mathrm{H}_{40} \mathrm{Cl}_{2} \mathrm{~N}_{2} \mathrm{Pt}_{2}$ : C, 56.82; $\mathrm{H}, 3.29 ; \mathrm{N}, 2.28$. Found: $\mathrm{C}, 56.45$; $\mathrm{H}, 3.32 ; \mathrm{N}, 2.32 .{ }^{1} \mathrm{H}-\mathrm{RMN}\left(400 \mathrm{MHz}\right.$, DMSO-d6): $\delta 9.44\left(\mathrm{~s}, 1 \mathrm{H},{ }^{3} \mathrm{~J}_{\mathrm{PtH}}=\right.$ $\left.42 \mathrm{~Hz}, \mathrm{H}^{1}\right), 9.25\left(\mathrm{~s},{ }^{3} \mathrm{~J}_{\mathrm{PtH}}=112 \mathrm{~Hz}, 1 \mathrm{H}, H \mathrm{C}=\mathrm{N}\right), 8.45-8.26(\mathrm{~m}, 4 \mathrm{H})$, $7.88(\mathrm{~d}, \mathrm{~J}=8.2 \mathrm{~Hz}, 1 \mathrm{H}), 7.84(\mathrm{~d}, \mathrm{~J}=8.1 \mathrm{~Hz}, 1 \mathrm{H}), 7.61(\mathrm{~m}, 2 \mathrm{H}), 7.50(\mathrm{t}$, $\mathrm{J}=7.9 \mathrm{~Hz}, 1 \mathrm{H}), 7.33(\mathrm{~d}, \mathrm{~J}=8.4 \mathrm{~Hz}, 2 \mathrm{H}), 7.25(\mathrm{~d}, \mathrm{~J}=8.5 \mathrm{~Hz}, 2 \mathrm{H}), 2.66$ (q, J = 7.6 Hz, $\left.2 \mathrm{H}, \mathrm{CH}_{2} \mathrm{CH}_{3}\right), 1.22\left(\mathrm{t}, \mathrm{J}=7.6 \mathrm{~Hz}, 3 \mathrm{H}, \mathrm{CH}_{2} \mathrm{CH}_{3}\right) . \mathrm{IR}(\mathrm{KBr}$, $\left.\mathrm{cm}^{-1}\right): 1554 v(\mathrm{C}=\mathrm{N})$.
Preparation of 4. To a suspension of $3(0.129 \mathrm{~g}, 0.106 \mathrm{mmol})$ in dry dichloromethane $(30 \mathrm{~mL})$ [TI(acac)] $(0.066 \mathrm{~g}, 0.218 \mathrm{mmol})$ was added. After $6 \mathrm{~h}$ stirring the white precipitate of $\mathrm{TICl}$ was filtered off, the solution was evaporated to dryness. The pure product was obtained by column chromatography on silica gel $\left(\mathrm{CH}_{2} \mathrm{Cl}_{2}\right)$. Yield $0.109 \mathrm{~g}(74 \%)$. Anal. Calcd. for $\mathrm{C}_{34} \mathrm{H}_{27} \mathrm{NO}_{2} \mathrm{Pt}$ : C, 60.35; $\mathrm{H}, 4.02 ; \mathrm{N}$, 2.07. Found: $\mathrm{C}, 60.10 ; \mathrm{H}, 3.96 ; \mathrm{N}, 2.21 .{ }^{1} \mathrm{H}$ NMR $\left(400 \mathrm{MHz}, \mathrm{CDCl}_{3}\right): \delta$ $8.94\left(\mathrm{~s}^{3} \mathrm{~J}_{\mathrm{PtH}}=133.1 \mathrm{~Hz}, 1 \mathrm{H}, H \mathrm{C}=\mathrm{N}\right), 8.62\left(\mathrm{~s},{ }^{3} \mathrm{JPtH}_{\mathrm{PtH}}=35 \mathrm{~Hz} 1 \mathrm{H}, \mathrm{H}^{1}\right)$, $8.41(\mathrm{~d}, \mathrm{~J}=7.2 \mathrm{~Hz}, 1 \mathrm{H}), 8.22(\mathrm{~d}, \mathrm{~J}=7.2 \mathrm{~Hz}, 1 \mathrm{H}), 8.12(\mathrm{~d}, \mathrm{~J}=7.5 \mathrm{~Hz}$, $1 \mathrm{H}), 7.89(\mathrm{~d}, \mathrm{~J}=8.1 \mathrm{~Hz}, 1 \mathrm{H}), 7.70(\mathrm{t}, \mathrm{J}=8.0 \mathrm{~Hz}, 2 \mathrm{H}), 7.59-7.46(\mathrm{~m}$, $5 \mathrm{H}), 7.42(\mathrm{t}, \mathrm{J}=7.9 \mathrm{~Hz}, 1 \mathrm{H}), 7.28(\mathrm{~d}, \mathrm{~J}=8.2 \mathrm{~Hz}, 1 \mathrm{H}), 5.49(\mathrm{~s}, 1 \mathrm{H}), 2.74$ $\left(q, J=7.6 \mathrm{~Hz}, 2 \mathrm{H}, \mathrm{CH}_{2} \mathrm{CH}_{3}\right), 2.15(\mathrm{~s}, 3 \mathrm{H}), 1.86(\mathrm{~s}, 3 \mathrm{H}), 1.30(\mathrm{t}, \mathrm{J}=7.6$ $\left.\mathrm{Hz}, 3 \mathrm{H}, \mathrm{CH}_{2} \mathrm{CH}_{3}\right) .{ }^{195} \mathrm{Pt} \mathrm{NMR}\left(\mathrm{CDCl}_{3}, 107 \mathrm{MHz}\right): \delta-2874 \mathrm{ppm}$. IR (KBr, $\left.\mathrm{cm}^{-1}\right): 1559 v(\mathrm{C}=\mathrm{N})$.

Preparation of 5. A suspension of $\mathbf{3}(0.079 \mathrm{~g}, 0.065 \mathrm{mmol})$ in dry dichloromethane $(30 \mathrm{~mL})$ was treated with a solution of $\mathrm{KOH}$ in methanol $(520 \mathrm{~mL}, 0.259 \mathrm{mmol}, 0.5 \mathrm{M})$ and $\mathrm{CS}_{2}(0.13 \mathrm{~mL}, 2.19$ $\mathrm{mmol})$. The red solution was stirred $24 \mathrm{~h}$ at room temperature, then the solvent was evaporated in vacuum. The residue was redissolved in dichloromethane, and the cloudy solution was filtered through a Kieselguhr filter. Complex 4 was precipitated by the addition of diethyl ether $(10 \mathrm{~mL})$ as a dark red solid $(0.053 \mathrm{~g}$, $60 \%$ ). Anal. Calcd. for $\mathrm{C}_{31} \mathrm{H}_{23} \mathrm{NOPtS}_{2}$ : C, 54.38; $\mathrm{H}, 3.38 ; \mathrm{N}, 2.04$. Found: $\mathrm{C}, 54.12 ; \mathrm{H}, 3.41 ; \mathrm{N}, 1.98 .{ }^{1} \mathrm{H}$ NMR $\left(400 \mathrm{MHz}, \mathrm{CDCl}_{3}\right): \delta 9.12$ $\left(\mathrm{s},{ }^{3} \mathrm{~J}_{\mathrm{PtH}}=120 \mathrm{~Hz}, 1 \mathrm{H}, H \mathrm{C}=\mathrm{N}\right), 8.33(\mathrm{~d}, \mathrm{~J}=7.4 \mathrm{~Hz}, 1 \mathrm{H}), 8.24(\mathrm{~d}, \mathrm{~J}=7.6$ $\mathrm{Hz}, 1 \mathrm{H}), 8.17\left(\mathrm{~s}^{3}{ }^{3} \mathrm{PtH}_{\mathrm{PtH}}=79 \mathrm{~Hz}, 1 \mathrm{H}, \mathrm{H}^{1}\right), 8.16(\mathrm{~d}, \mathrm{~J}=7.7 \mathrm{~Hz}, 1 \mathrm{H}), 7.98$ $(d, J=8.2 \mathrm{~Hz}, 1 \mathrm{H}), 7.74(\mathrm{~d}, \mathrm{~J}=8.0 \mathrm{~Hz}, 1 \mathrm{H}), 7.71(\mathrm{~d}, \mathrm{~J}=8.2 \mathrm{~Hz}, 1 \mathrm{H})$, $7.57-7.45(\mathrm{~m}, 3 \mathrm{H}), 7.39(\mathrm{~d}, \mathrm{~J}=8.5 \mathrm{~Hz}, 2 \mathrm{H}), 7.29(\mathrm{~d}, \mathrm{~J}=8.2 \mathrm{~Hz}, 2 \mathrm{H})$, $4.28(\mathrm{~s}, 3 \mathrm{H}), 2.72\left(\mathrm{q}, \mathrm{J}=7.6 \mathrm{~Hz}, 2 \mathrm{H}, \mathrm{CH}_{2} \mathrm{CH}_{3}\right), 1.28(\mathrm{t}, \mathrm{J}=7.6 \mathrm{~Hz}, 3 \mathrm{H}$, $\left.\mathrm{CH}_{2} \mathrm{CH}_{3}\right) \cdot{ }^{195} \mathrm{Pt} \mathrm{NMR}\left(\mathrm{CDCl}_{3}, 107 \mathrm{MHz}\right): \delta-3939 \mathrm{ppm}$. IR $\left(\mathrm{KBr}, \mathrm{cm}^{-1}\right)$ : $1551 v(\mathrm{C}=\mathrm{N})$.

Preparation of 6. Sodium diethyldithiocarbamate trihydrate $(0.041$ $\mathrm{g}, 0.176 \mathrm{mmol})$ was added to a suspension of $\mathbf{3}(0.071 \mathrm{~g}, 0.058$ $\mathrm{mmol}$ ) in dichloromethane/acetone $(1: 1,18 \mathrm{~mL})$. The mixture was stirred $24 \mathrm{~h}$ at room temperature, then the solvents were distilled off, and the residue was redissolved in dichloromethane, and the cloudy solution was filtered through a Kieselguhr filter. Complex 6 was precipitated by the addition of diethyl ether $(15 \mathrm{~mL})$ as a dark red solid which was filtered, washed with diethyl ether $(2 \times 5 \mathrm{~mL})$ and dried in vacuo. (0.067 g, 80\%). Anal. Calcd. for $\mathrm{C}_{34} \mathrm{H}_{30} \mathrm{~N}_{2} \mathrm{PtS}_{2}: \mathrm{C}$, 56.26; $\mathrm{H}, 4.16 ; \mathrm{N}, 3.86$. Found: $\mathrm{C}, 55.85 ; \mathrm{H}, 4.13 ; \mathrm{N}, 3.88 .{ }^{1} \mathrm{H}$ NMR $\left(400 \mathrm{MHz}, \mathrm{CDCl}_{3}\right): \delta 9.19\left(\mathrm{~s},{ }^{3} \mathrm{~J}_{\mathrm{PtH}}=111.3 \mathrm{~Hz}, 1 \mathrm{H}, \mathrm{HC}=\mathrm{N}\right), 8.38(\mathrm{~d}, \mathrm{~J}=$ $7.5 \mathrm{~Hz}, 1 \mathrm{H}), 8.23(\mathrm{~d}, \mathrm{~J}=7.4 \mathrm{~Hz}, 1 \mathrm{H}), 8.19\left(\mathrm{~s},{ }^{3} \mathrm{~J}_{\mathrm{PtH}}=60 \mathrm{~Hz}, 1 \mathrm{H}, \mathrm{H}^{1}\right)$, $8.15(d, J=7.5 \mathrm{~Hz}, 1 \mathrm{H}), 7.99(\mathrm{~d}, \mathrm{~J}=8.2 \mathrm{~Hz}, 1 \mathrm{H}), 7.70(\mathrm{t}, \mathrm{J}=8.3 \mathrm{~Hz}$, $2 \mathrm{H}), 7.57-7.43(\mathrm{~m}, 3 \mathrm{H}), 7.40(\mathrm{~d}, \mathrm{~J}=8.4 \mathrm{~Hz}, 2 \mathrm{H}), 7.28(\mathrm{~d}, \mathrm{~J}=8.5 \mathrm{~Hz}$, $2 \mathrm{H}), 3.90-3.64(\mathrm{~m}, 4 \mathrm{H}), 2.72\left(\mathrm{q}, \mathrm{J}=7.6 \mathrm{~Hz}, 2 \mathrm{H}, \mathrm{CH}_{2} \mathrm{CH}_{3}\right), 1.43(\mathrm{t}, \mathrm{J}=$ $\left.7.2 \mathrm{~Hz}, 3 \mathrm{H}, \mathrm{CH}_{2} \mathrm{CH}_{3}\right), 1.36-1.22(\mathrm{~m}, 6 \mathrm{H}) .{ }^{195} \mathrm{Pt} \mathrm{NMR}\left(\mathrm{CDCl}_{3}, 107\right.$ $\mathrm{MHz}): \delta-3712 \mathrm{ppm}$. IR $\left(\mathrm{KBr}, \mathrm{cm}^{-1}\right): 1553 v(\mathrm{C}=\mathrm{N})$.

Preparation of 7. To a solution of $2(0.091 \mathrm{~g}, 0.107 \mathrm{mmol})$ in dry THF (20 mL) Mel (140 mL, $2.221 \mathrm{mmol})$ was added. After 3 days stirring at room temperature the solvent was removed in vacuo and the red solid was washed with hexane $(2 \times 5 \mathrm{~mL})$ and diethyl ether $(2 \times 5 \mathrm{~mL})$. The complex was recrystallized in acetone/hexane. Yield: $0.062 \mathrm{~g}(58 \%)$. Anal. Calcd. for $\mathrm{C}_{49} \mathrm{H}_{41} \mathrm{INPPt}$ : 
C, 59.04; H, 4.14; N, 1.40. Found: $C, 58.71 ; H, 4.04 ; N, 1.64 .{ }^{1} \mathrm{H}-\mathrm{RMN}$ $\left(400 \mathrm{MHz}, \mathrm{CDCl}_{3}\right): \delta 8.82\left(\mathrm{~d},{ }^{4} \mathrm{~J}_{\mathrm{PH}}=2.0 \mathrm{~Hz},{ }^{3} \mathrm{~J}_{\mathrm{PtH}}=43.9 \mathrm{~Hz}, 1 \mathrm{H}, \mathrm{HC}=\mathrm{N}\right)$, $8.25(\mathrm{~d}, \mathrm{~J}=7.4 \mathrm{~Hz}, 1 \mathrm{H}), 8.17(\mathrm{~d}, \mathrm{~J}=7.5 \mathrm{~Hz}, 1 \mathrm{H}), 8.11(\mathrm{~d}, \mathrm{~J}=7.4 \mathrm{~Hz}$, $1 \mathrm{H}), 7.86\left(\mathrm{~s},{ }^{3} \mathrm{~J}_{\mathrm{PtH}}=48.3 \mathrm{~Hz}, 1 \mathrm{H}, \mathrm{H}^{1}\right), 7.76(\mathrm{~d}, \mathrm{~J}=8.1 \mathrm{~Hz}, 1 \mathrm{H}), 7.75(\mathrm{~d}$, $\mathrm{J}=8.1 \mathrm{~Hz}, 1 \mathrm{H}), 7.69(\mathrm{~d}, \mathrm{~J}=8.2 \mathrm{~Hz}, 1 \mathrm{H}), 7.55(\mathrm{t}, \mathrm{J}=7.8 \mathrm{~Hz}, 1 \mathrm{H}), 7.50$ $(\mathrm{t}, \mathrm{J}=7.8 \mathrm{~Hz}, 1 \mathrm{H}), 7.41(\mathrm{t}, \mathrm{J}=7.9 \mathrm{~Hz}, 1 \mathrm{H}), 7.33-7.23(\mathrm{~m}, 10 \mathrm{H}), 7.04$ (td, 7.3 Hz, 1.5 Hz, 3H), 6.93 (td, J = 7.7, 2.2 Hz, 6H), 2.77 (q, J = 7.6 $\mathrm{Hz}, 2 \mathrm{H}, \mathrm{CH}_{2} \mathrm{CH}_{3}$ ), $1.84\left(\mathrm{~d},{ }^{3} \mathrm{JPH}_{\mathrm{PH}}=8.1 \mathrm{~Hz},{ }^{2} \mathrm{~J}_{\mathrm{PtH}}=71.5 \mathrm{~Hz}, 3 \mathrm{H}\right), 1.63$ (d, $\left.{ }^{3} \mathrm{~J}_{\mathrm{HP}}=7.2 \mathrm{~Hz},{ }^{2} \mathrm{~J}_{\mathrm{HPt}}=60.2 \mathrm{~Hz}, 3 \mathrm{H}\right), 1.34\left(\mathrm{t}, \mathrm{J}=7.5 \mathrm{~Hz}, 3 \mathrm{H}, \mathrm{CH}_{2} \mathrm{CH}_{3}\right)$. ${ }^{31} \mathrm{P}\left\{{ }^{1} \mathrm{H}\right\} \mathrm{RMN}\left(\mathrm{CDCl}_{3}, 162 \mathrm{MHz}\right): \delta-4.6\left(\mathrm{~s},{ }^{1} \mathrm{~J}_{\mathrm{PtP}}=1015 \mathrm{~Hz}\right) .{ }^{195} \mathrm{Pt} \mathrm{NMR}$ $\left(\mathrm{CDCl}_{3}, 107 \mathrm{MHz}\right): \delta-3345 \mathrm{ppm}$. IR $\left(\mathrm{KBr}, \mathrm{cm}^{-1}\right): 1560 \mathrm{v}(\mathrm{C}=\mathrm{N})$.

Preparation of 8 . To a solution of $4(0.021 \mathrm{~g}, 0.032 \mathrm{mmol})$, in dry THF, Mel ( $22 \mathrm{~mL}, 0.348 \mathrm{mmol}$ ) was added. After $24 \mathrm{~h}$ stirring at room temperature a dark red precipitate was formed. The precipitate was filtered out, washed with diethyl ether $(2 \times 5 \mathrm{~mL})$ and dried in vacuo. Yield: $0.020 \mathrm{~g}$ (78\%). Anal. Calcd. for $\mathrm{C}_{35} \mathrm{H}_{30} \mathrm{INO}_{2} \mathrm{Pt}$ : C, 51.35; $\mathrm{H}, 3.69 ; \mathrm{N}, 1.71$. Found: $\mathrm{C}, 50.94 ; \mathrm{H}, 3.49 ; \mathrm{N}$, 1.78. ${ }^{1} \mathrm{H} \mathrm{NMR}\left(400 \mathrm{MHz}, \mathrm{CDCl}_{3}\right): \delta=8.83\left(\mathrm{~s},{ }^{3} \mathrm{~J}_{\mathrm{PtH}}=109.4 \mathrm{~Hz}, 1 \mathrm{H}\right.$, $H C=N), 8.64\left(s^{3}{ }^{3} \mathrm{JtH}_{\mathrm{PtH}}=27 \mathrm{~Hz}, 1 \mathrm{H}, \mathrm{H}^{1}\right), 8.48(\mathrm{~d}, \mathrm{~J}=7.4 \mathrm{~Hz}, 1 \mathrm{H}), 8.29(\mathrm{~d}$, $\mathrm{J}=7.4 \mathrm{~Hz}, 1 \mathrm{H}), 8.25(\mathrm{~d}, \mathrm{~J}=7.8 \mathrm{~Hz}, 1 \mathrm{H}), 7.99(\mathrm{~d}, \mathrm{~J}=8.5 \mathrm{~Hz}, 1 \mathrm{H}), 7.82$ (d, J = 7.8 Hz, 1H), $7.77(d, J=7.8 \mathrm{~Hz}, 1 \mathrm{H}), 7.71(\mathrm{~d}, \mathrm{~J}=8.2 \mathrm{~Hz}, 2 \mathrm{H})$, $7.64-7.54(\mathrm{~m}, 3 \mathrm{H}), 7.30(\mathrm{~d}, \mathrm{~J}=7.9 \mathrm{~Hz}, 2 \mathrm{H}), 5.55(\mathrm{~s}, 1 \mathrm{H}), 2.75$ (q, J = $\left.7.4 \mathrm{~Hz}, 2 \mathrm{H}, \mathrm{CH}_{2} \mathrm{CH}_{3}\right), 2.28(\mathrm{~s}, 3 \mathrm{H}), 2.00(\mathrm{~s}, 3 \mathrm{H}), 1.47\left(\mathrm{~s},{ }^{2} \mathrm{~J}_{\mathrm{ptH}}=65.2 \mathrm{~Hz}\right.$, $3 \mathrm{H}), 1.31\left(\mathrm{t}, \mathrm{J}=7.6 \mathrm{~Hz}, 3 \mathrm{H}, \mathrm{CH}_{2} \mathrm{CH}_{3}\right) .{ }^{195} \mathrm{Pt} \mathrm{NMR}\left(\mathrm{CDCl}_{3}, 107 \mathrm{MHz}\right): \delta-$ $2392 \mathrm{ppm}$. IR $\left(\mathrm{KBr}, \mathrm{cm}^{-1}\right)$ : $1558 v(\mathrm{C}=\mathrm{N})$.

Preparation of 9. To a solution of $6(0.044 \mathrm{~g}, 0.060 \mathrm{mmol})$, in dry acetone, Mel ( $41 \mathrm{~mL}, 0.651 \mathrm{mmol}$ ) was added. After 3-4 days stirring at room temperature a dark red precipitate was formed. The precipitate was filtered out, washed with diethyl ether $(2 \times 5$ $\mathrm{mL}$ ) and dried in vacuo. Yield: $0.044 \mathrm{~g}(87 \%)$. Anal. Calcd. for $\mathrm{C}_{35} \mathrm{H}_{33} \mathrm{IN}_{2} \mathrm{PtS}_{2}$ : C, 48.44; $\mathrm{H}, 3.83 ; \mathrm{N}, 3.23$. Found: $\mathrm{C}, 48.15 ; \mathrm{H}, 3.86 ; \mathrm{N}$, 3.29. ${ }^{1} \mathrm{H} \mathrm{NMR}\left(400 \mathrm{MHz}, \mathrm{CDCl}_{3}\right): \delta 9.05\left(\mathrm{~s},{ }^{3} \mathrm{~J}_{\mathrm{PtH}}=89.9 \mathrm{~Hz}, 1 \mathrm{H}\right.$, $H C=N), 8.45(\mathrm{~d}, \mathrm{~J}=7.2 \mathrm{~Hz}, 1 \mathrm{H}), 8.26(\mathrm{~d}, \mathrm{~J}=7.2 \mathrm{~Hz}, 1 \mathrm{H}), 8.21$ (d, J = $8.2 \mathrm{~Hz}, 1 \mathrm{H}), 8.20\left(\mathrm{~s}^{3} \mathrm{~J}_{\mathrm{PtH}}=41.2 \mathrm{~Hz}, 1 \mathrm{H}, \mathrm{H}^{1}\right), 8.04(\mathrm{~d}, \mathrm{~J}=8.2 \mathrm{~Hz}, 1 \mathrm{H})$, $7.79(\mathrm{~d}, \mathrm{~J}=8.0 \mathrm{~Hz}, 1 \mathrm{H}), 7.74(\mathrm{~d}, \mathrm{~J}=8.0 \mathrm{~Hz}, 1 \mathrm{H}), 7.65-7.49(\mathrm{~m}, 5 \mathrm{H})$, $7.30(\mathrm{~d}, \mathrm{~J}=8.2 \mathrm{~Hz}, 2 \mathrm{H}), 3.84-3.53\left(\mathrm{~m}, 4 \mathrm{H}, \mathrm{NCH}_{2} \mathrm{CH}_{3}\right), 2.74(\mathrm{q}, \mathrm{J}=$ $\left.7.6 \mathrm{~Hz}, 2 \mathrm{H}, \mathrm{CH}_{2} \mathrm{CH}_{3}\right), 1.74\left(\mathrm{~s},{ }^{2} \mathrm{~J}_{\mathrm{PtH}}=67.5 \mathrm{~Hz}, 3 \mathrm{H}\right), 1.42(\mathrm{t}, \mathrm{J}=7.2 \mathrm{~Hz}$, $\left.3 \mathrm{H}, \mathrm{CH}_{2} \mathrm{CH}_{3}\right), 1.37-1.24\left(\mathrm{~m}, 6 \mathrm{H}, \mathrm{NCH}_{2} \mathrm{CH}_{3}\right) .{ }^{195} \mathrm{Pt} \mathrm{NMR}\left(\mathrm{CDCl}_{3}, 107\right.$ $\mathrm{MHz}): \delta$-3189 ppm. IR $\left(\mathrm{KBr}, \mathrm{cm}^{-1}\right): 1558 \mathrm{v}(\mathrm{C}=\mathrm{N})$.

$X$-ray Crystal Structure Analysis. Single crystals of 4, $\mathbf{6}$ and $\mathbf{7}$ suitables for $\mathrm{X}$-ray diffraction studies were obtained from slow diffusion of hexane into a solution (chloroform solution for $\mathbf{4}$ and $\mathbf{6}$, and an acetone solution for 7 ) of the products at $-20^{\circ} \mathrm{C}$. Relevant crystallographic details are given in Table 4 . Crystals were mounted in glass fibers, and diffraction measurements were made using a Bruker AXS SMART 1000 and Varian Supernova area-detector diffractometers with Mo- $K_{\alpha}$ radiation $\left(\lambda=0.71073 \AA\right.$ ).${ }^{41}$ Intensities were integrated from several series of exposures, each exposure covering $0.3^{\circ}$ in $\omega$, the total data set being a hemisphere. ${ }^{42}$ Absorption corrections were applied, based on multiple and symmetry-equivalent measurements. ${ }^{43}$ The structures were solved by direct methods and refined by least squares on weighted $\mathrm{F}^{2}$ values for all reflections (see Table 4). ${ }^{44}$ The non-hydrogen atoms were refined anisotropically and hydrogen atoms were placed at idealized positions and refined using the riding model. Complex neutral-atom scattering factors were used. ${ }^{45}$ The molecular structures were created with Olex2 program. ${ }^{46}$ Crystallographic data (excluding structure factors) for the structures reported in this paper have been deposited with the Cambridge Crystallographic Data Centre as Supplementary publications with the deposition numbers CCDC-1409783 for 4, numbers CCDC-1409784 for 6 and CCDC-1409785 for 7. Copies of the data can be obtained free of charge on application to the CCDC, 12 Union Road, Cambridge CB2 1EZ, U.K. [Fax: (internat.) + 44-1223/336-033; Email: deposit@ccdc.cam.ac.uk]. 
Table 4 Crystal and structure refinement data for 4,6 and 7

\begin{tabular}{|c|c|c|c|}
\hline Compound & 4 & 6 & $7 \cdot \mathrm{C}_{3} \mathrm{H}_{6} \mathrm{O}$ \\
\hline Empirical formula & $\mathrm{C}_{34} \mathrm{H}_{27} \mathrm{NO}_{2} \mathrm{Pt}$ & $\mathrm{C}_{34} \mathrm{H}_{30} \mathrm{~N}_{2} \mathrm{O}_{2} \mathrm{PtS}_{2}$ & $\mathrm{C}_{52} \mathrm{H}_{47}$ INOPPt \\
\hline Formula weight & 676.66 & 725.81 & 1054.87 \\
\hline Temperature (K) & $298(2)$ & $293(2)$ & $293(2)$ \\
\hline Wavelength $(\AA ̊)$ & 0.71073 & 0.71073 & 0.71073 \\
\hline Crystal system & Triclinic & Monoclinic & Monoclinic \\
\hline Space group & $\mathrm{P}-1$ & P 1 21/c 1 & P 1 21/c 1 \\
\hline$a(\AA)$ & $10.941(3)$ & $9.2229(3)$ & $17.4454(5)$ \\
\hline$b(\AA)$ & $11.036(3)$ & $7.4651(2)$ & $10.8317(2)$ \\
\hline$c(\AA)$ & $12.736(3)$ & $40.1846(12)$ & $24.4189(6)$ \\
\hline$\alpha$ (deg) & $88.821(4)$ & 90 & 90 \\
\hline$\beta$ (deg) & $73.295(3)$ & $94.748(3)$ & $109.196(3)$ \\
\hline$\nu$ (deg) & $60.986(3)$ & 90 & 90 \\
\hline$V\left(\AA^{3}\right)$ & $1275.1(5)$ & $2757.21(14)$ & $4357.72(18)$ \\
\hline$Z$ & 2 & 4 & 4 \\
\hline$D_{\text {calc }}\left(\mathrm{g} \mathrm{cm}^{-3}\right)$ & 1.762 & 1.748 & 1.608 \\
\hline Absorpt. coefficient $\left(\mathrm{mm}^{-1}\right)$ & 5.536 & 5.268 & 4.004 \\
\hline$F(000)$ & 664 & 1432 & 2080 \\
\hline Crystal size $(\mathrm{mm})$ & $0.27 \times 0.16 \times 0.15$ & $0.40 \times 0.18 \times 0.09$ & $0.21 \times 0.16 \times 0.07$ \\
\hline Theta range for data collection & 1.69 to 26.42 & 2.03 to 29.83 & 3.00 to 26.37 \\
\hline Reflections collected & 11222 & 15282 & 25991 \\
\hline Independent reflections & 5200 & 6759 & 8700 \\
\hline Absorption correction & Multi-scan & Gaussian & Analytical \\
\hline Max. and min. transmission factor & 1.000 and 0.5399 & 0.671 and 0.359 & 0.767 and 0.518 \\
\hline Data/restraints/parameters & $5200 / 0 / 346$ & 6759 / 0 / 355 & 8700 / 0 / 519 \\
\hline Goodness-of-fit on $F^{2}$ & 1.054 & 1.253 & 0.979 \\
\hline$R_{1}[I>2 \mathrm{~s}(\mathrm{I})]$ & 0.0188 & 0.0463 & 0.0324 \\
\hline$w R_{2}$ (all data) & 0.0460 & 0.0753 & 0.0655 \\
\hline
\end{tabular}

\section{Acknowledgements}

We thank the Spanish Ministerio de Economía y Competitividad (CTQ2014-52796-P) and the Junta de Castilla y León (Project VA302U13), for financial support. Allocation of computer facilities at IQTCUB is also acknowledged. We are grateful to Sergio Ferrero (IU/Cinquima, Valladolid) for experimental help on ${ }^{195} \mathrm{Pt}$ NMR spectra.

\section{Notes and references}

1 See for example: (a) F. Würthner, Chem. Commun. 2004, 1564; (b) C. Li, H. Wonneberger, Adv Mater. 2012, 24, 613; (c) C. Huang, S. Barlow and S. R. Marder, J. Org. Chem. 2011, 76, 2386; (d) Y. Lin, Y. Wang, J Wang, J. Hou, Y. Li, D. Zhu and X. Zhan, X. Adv. Mater. 2014, 26, 5137; (e) Y. Li,
T. Liu, H. Liu, M. Tian and Y. Li, Y. Acc. Chem. Res. 2014, 47, $1186(f)$ L. Schmidt-Mende, A. Fechtenkötter, K. Müllen, E. Moons, R. Friend and J. D. MacKenzie, Science 2011, 293, 1119; ( $g$ ) F. Würtner, T. E. Kaiser and C. R. Saha-Möller, Angew. Chem., Int. Ed. 2011, 50, 3376.

2 F. Castellano, Dalton Trans., 2012, 41, 8493 and references cited therein.

3 Y. Y. Chia and M. G. Tay, Dalton Trans., 2014, 43, 13159.

4 S. Lentijo, G. Aullón, J. A. Miguel and P. Espinet, Dalton Trans., 2013, 42, 6353.

5 S. Lentijo, J. E. Expósito, G. Aullón, J. A. Miguel and P. Espinet, Dalton Trans., 2014, 43, 10885.

6 (a) S. Lentijo, J. A. Miguel and P. Espinet, Organometallics 2011, 30, 1059; (b) S. Lentijo, J. A. Miguel and P. Espinet, Dalton Trans., 2011, 40, 7602

7 (a) M. Crespo, X. Solans and M. Font-Bardía, J. Organometallic Chem. 1996, 518, 105; (b) C. M. Anderson, M. Crespo, M. C. Jennings, A. J. Lough, G. Ferguson and R. J. Puddephatt, J. Organometallics 1991, 10, 2672; (c) M. Crespo, M. Font-Bardía and X. Solans, Organometallics 2004, 23, 1708; 
(d) C. Gallego, M. Martínez and V. C. Safont, Organometallics 2007, 26, 15 J. Rodríguez, J. Zafrilla, J. Albert, M. Crespo, J. Granell, T. Calvet and M. 527; (e) T. Wang and J. A. Love, Organometallics 2008, 27, 3290; (f) J. Font-Bardia, J. Organomet. Chem. 2009, 694, 2467.

Albert, R. Bosque, M. Crespo, J. Granell, J. Rodríguez and J. Zafrilla, 16 M. Crespo, X. Solans and M. Font-Bardía, Organometallics, 1995, 691, Organometallics 2010, 29, 4619; (g) M. Crespo, Organometallics 2012, 31, 355. 1216.

8 (a) R. Cortés, M. Crespo, L. Davin, R. Martín, J. Quirante, D. Ruiz, R. Messeguer, C. Calvis, L. Baldomà, J. Badia, M. Font-Bardía, T. Calvet and M. Cascante, Eur. J. Med. Chem. 2012, 54, 557; (b) L. Keyes, T. Wang, B.O. Patrick and J. A. Love, Inorg. Chim. Acta 2012, 380, 284; (c) M. Bortoluzzi, G. Paolucci, B. Pitteri, P. Zennaro and V. Bertolasi, J. Organomet. Chem. 2011, 696, 2565; (d) J. Buey, S. Coco, L. Díez, P. Espinet, J. M. MartínÁlvarez and J. A. Miguel, Organometallics 1998, 17, 1750; (e) M. Crespo, M. Font-Bardía and X. Solans, Organometallics 2004, 23, 1708; (f) P. Chellan, K. M. Land, A. Shokar, A. Au, S. H. An, C. M. Clavel, P. J. Dyson, C. de Kock, P. J. Smith, K. Chibale and G. S. Smith, Organometallics 2012, 31, 5791; $(g)$ K. Tan, X. Yang, Y. Li, Y. Huang, S. A. Pullarkat and P. Leung, Organometallics 2012, 31, 8407; (h) M. Ilis, M. Micutz, F. Dumitrascu, I. Pasuk, Y. Molard, T. Roisnel and V. Cîrcu, Polyhedron 2014, 69, 31; (i) J. S. Fossey and C. J. Richards, Tetrahedron Lett. 2003, 44, 8773.

9 (a) J. Kalinowski, V. Fattori, M. Cocchi and J. A. G. Williams, Coord. Chem. Rev. 2011, 255, 2401; (b) J. A. G. Williams, S. Develay, D.L. Rochester and L. Murphy, Coord. Chem. Rev. 2008, 252, 2596.

10 P. T. Chou and Y. Chi, Chem. Eur. J. 2007, 13, 380.

11 (a) Y. Y. Scaffidi-Domianello, A. A. Nazarov, M. Haukka, M. Galanski, B. K. Keppler, J. Schneider, P. Du, R. Eisenberg and V. Y. Kukushkin, Inorg. Chem. 2007, 46, 4469; (b) A. Caubet, C. López, X. Solans and M. FontBardía, J. Organomet. Chem. 2003, 669, 164; (c) S. Pandya, K. C. Moss, M. R. Bryce, A. S. Batsanov, M. A. Fox, V. Jankus, H. A. Al Attar and A. P. Monkman, Eur. J. Inorg. Chem. 2010, 1963; (d) O. A. Blackburn, B. J. Coe, M. Helliwell and J. Raftery, Organometallics 2012, 31, 5307; (e) C. M. Anderson, M. A. Weinstein, J. Morris, N. Kfoury, L. Duman, T. A. Balema, A. Kreider-Mueller, P. Scheetz, S. Ferrara, M. Chierchia and J. M. Tanski, J. Organomet. Chem. 2013, 723, 188; (f) A. Gandioso, J. Valle-Sistac, L. Rodríguez, M. Crespo and M. Font-Bardía, Organometallics 2014, 33, 561.

12 (a) L. Chassot, A. von Zelewsky, D. Sandrini, M. Maestri and V. Balzani, J. Am. Chem. Soc. 1986, 108, 6084; (b) F. Barigelletti, D. Sandrini, M. Maestri, V. Balzani, A. von Zelewsky, L. Chassot, P. Jolliet and U. Maeder, Inorg. Chem. 1988, 27, 3644.

13 (a) D. M. Jenkins, S. Bernhard, Inorg. Chem. 2010, 49, 11297; (b) M. La Deda, A. Crispini, I. Aiello, M. Ghedini, M. Amati, S. Belviso and F. Lelj, Dalton Trans. 2011, 40, 5259; (c) E. Anger, M. Rudolph, L. Norel, S. Zrig, C. Shen, N. Vanthuyne, L. Toupet, J. A. G. Williams, C. Roussel, J. Autschbach, J. Crassous, R. Reau, Chem. Eur. J. 2011, 17, 14178; (d) F. Juliá, D. Bautista, J. M. Fernández-Hernández and P. González-Herrero, Chem. Sci. 2014, 5, 1875; (e) F. Juliá, G. Aullón, D. Bautista and P. González-Herrero, Chem. Eur. J. 2014, 20, 17346.

14 W. W. Yam and K. M. Wong, Chem. Commun., 2011, 47, 11579.
17 M. Crespo, M. Font-Bardía and X. Solans, J Organomet. Chem. 2006, 691, 444.

18 a) P. S. Pregosin, F. Wombacher, A. Albinati and F. Lianza, J. Organomet. Chem. 1991, 418, 249. b) J. Buey, L. Díez, P. Espinet, H.-S. Kitzerow and J. A. Miguel, Chem. Mater. 1996, 8, 2375.

19 M. Crespo, M. Font-Bardía and X. Solans, J. Organomet. Chem. 2006, 691, 444.

20 C. Anderson, M. Crespo, M. Font-Bardía, A. Klein, X. Solans, J. Organomet. Chem. 2000, 601, 22.

21 A. R. Karikachery, H. B. Lee, M. Masjedi, A. Ross, M. A. Moody, X. Cai, M. Chui, C. D. Hoff and P. R. Sharp Inorg. Chem. 2013, 52, 4113.

22 (a) A. Pidcock, R. E. Richards and L. M. Venanzi, J. Chem. Soc. A, 1966, 1707; (b) T. G. Appleton, H. C. Clark, L. E. Manzer, Coord.Chem. Rev. 1973, 10, 335.

23 J. R. Lakowicz, Principles of Fluorescence Spectroscopy, 3rd ed., Springer, New York, 2006.

24 M. Montalti, A. Credi, L. Prodi and M. T. Gandolfini, Handbook of Photochemistry, 3rd ed.; CRC Pres LLC: Boca Raton, FL, 2005.

25 (a) A. P. De Silva and R. A. D. D. Rupasinghe, Chem. Commun. 1985, 1669; (b) B. P. de Silva, H. Q. N. Lgunaratne, T. L. Gunnlangsson, A. J. M. Unzley, C. P. McCoy, J. T. Rademacher and T. E. Rice, Chem. Rev. 1997, 97, 1515; (c) R. Martínez-Máñez and F. Sancenón, Chem. Rev. 2003, 103, 4419.

26 Our calculations indicate the following metal contributions to the HOMO/LUMO orbitals of perylenyl complexes: Pt" HOMO 4\%, LUMO 5\%; $\mathrm{Pt}^{\mathrm{IV}}$ HOMO 0\%, LUMO 2\%.

27 J. J. Wilson and S. J. Lippard, Inorg. Chim. Acta, 2012, 389, 77.

28 E. J. New, R. Duan, J. Z. Zhang and T. W. Hambley, Dalton Trans., 2009, 3092.

29 (a) A. W. Czarnik, Acc. Chem. Res. 1994, 27, 302; (b) H. Wang, D. Wang, Q. Wang, X. Li and C. A. Schalley, Org. Biomol. Chem., 2010, 8, 1017; (c) N. I. Georgiev, A. R. Sakr, A. R. and V. B. Bojinov, Dyes Pigm. 2011, 91, 332e339; (d) X. J. Liu, N. Zhang, J. Zhou, T. J. Chang, C. L. Fang and D. H. Shangguan, Analyst 2013, 138, 901; (e) S. Malkondu, Tetrahedron, 2014, 70, 5580; (f) H. Wang, Y. Lang, H. Wang, J. Lou, H. Guo and X. Li, Tetrahedron, 2014, 70, 1997.

30 G. S. Hill; M. J. Irwin; C. J. Levy; L. M. Rendina and R. J. Puddephatt, Inorg Synth. 1998, 32, 149.

31 D. J. Mabbot, B. E. Mann and P. M. Maitlis, J. Chem. Soc., Dalton Trans., 1977, 294.

32 E. C. Taylor; G. H. Hawks and A. Mckillop, J. Am. Chem. Soc. 1968, 90, 2421.

33 F. López-Arbeloa, P. Ruiz-Ojeda and I. López-Arbeloa, J. Luminesc. 1989, 44, 105. 
34 Magde, D.; Brannon, J. H.; Cremers, T. L.; Olmsted, J. J. Phys. Chem. 1979, 83, 696.

35 M. J. Frisch, G. W. Trucks, H. B. Schlegel, G. E. Scuseria, M. A. Robb, J. R. Cheeseman, G. Scalmani, V. Barone, B. Mennucci, G. A. Petersson, H. Nakatsuji, M. Caricato, X. Li, H. P. Hratchian, A. F. Izmaylov, J. Bloino, G. Zheng, J. L. Sonnenberg, M. Hada, M. Ehara, K. Toyota, R. Fukuda, J. Hasegawa, M. Ishida, T. Nakajima, Y. Honda, O. Kitao, H. Nakai, T. Vreven, J. A. Montgomery, Jr., J. E. Peralta, F. Ogliaro, M. Bearpark, J. J. Heyd, E. Brothers, K. N. Kudin, V. N. Staroverov, T. Keith, R. Kobayashi, J. Normand, K. Raghavachari, A. Rendell, J. C. Burant, S. S. Iyengar, J. Tomasi, M. Cossi, N. Rega, J. M. Millam, M. Klene, J. E. Knox, J. B. Cross, V. Bakken, C. Adamo, J. Jaramillo, R. Gomperts, R. E. Stratmann, O. Yazyev, A. J. Austin, R. Cammi, C. Pomelli, J. W. Ochterski, R. L. Martin, K. Morokuma, V. G. Zakrzewski, G. A. Voth, P. Salvador, J. J. Dannenberg, S. Dapprich, A. D. Daniels, O. Farkas, J. B. Foresman, J. V. Ortiz, J. Cioslowski and D. J. Fox, Gaussian 09 (Revission B.1); Gaussian Inc.: Wallingford CT 2010.

36 (a) A. D. Becke, J. Chem. Phys. 1993, 98, 5648. (b) C. Lee, W. Yang and R. G. Parr, Phys. Rev. B 1988, 37, 785.

37 P. J. Hay and W. R. Wadt, J. Chem. Phys. 1985, 82, 299.

38 (a) P. C. Hariharan and J. A. Pople, Theoret. Chim. Acta 1973, 28, 213. (b) M. M. Francl, W. J. Petro, W. J. Hehre, J. S. Binkley, M. S. Gordon, D. J. DeFrees and J. A. Pople, J. Chem. Phys. 1982, 77, 3654.

39 (a) J. Tomasi, M. Persico, Chem. Rev. 1994, 94, 2027. (b) C. Amovilla, V. Barone, R. Cammi, E. Cancès, M. Cossi, B. Mennucci, C. S. Pomelli and J. Tomasi, Adv. Quantum Chem. 1998, 32, 227.

40 M. E. Casida, C. Jamorski, K. C. Casida and D. R. Salahub, J. Chem. Phys. 1998, 108, 4439.

41 (a) SMART V5.051 diffractometer control software, Bruker Analytical Xray Instruments Inc., Madison, WI, 1998; (b) CrysAlisPro, Oxford Diffraction Ltd., Version 1.171.33.48.

42 (a) SAINT V6.02 integration software, Bruker Analytical X-ray Instruments Inc., Madison, WI, 1999; (b) CrysAlisPro, Oxford Diffraction Ltd.,Version 1.171.33.48.

43 (a) G. M. Sheldrick, SADABS: A program for absorption correction with the Siemens SMART system; University of Göttingen: Germany, 1996; (b) CrysAlisPro, Oxford Diffraction Ltd.,Version 1.171.33.48.

44 SHELXTL program system version 5.1; Bruker Analytical X-ray Instruments Inc., Madison, WI, 1998.

45 International Tables for Crystallography, Kluwer, Dordrecht, 1992, vol. C.

46 O. V. Dolomanov, L. J. Bourhis, R J. Gildea, J. A. K. Howard and H. Puschmann, J. Appl. Cryst. 2009, 42, 339. 